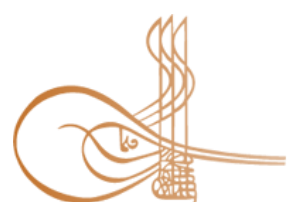

www.turkishstudies.net/language

\section{Turkish Studies - Language and Literature}

eISSN: 2667-5641

Research Article / Araștırma Makalesi

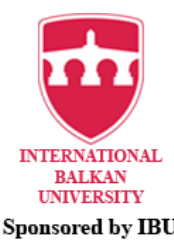

Sponsored by IBU

\title{
ملامح أسلوبيّة الاختيار ومعنى المعنى في نظريّة النَّظم عند الجرجانيّ في كتابه (دلائل الإعجاز)
}

\section{Cürcânî'nin "Delâilu'l-İ'câz” Adlı Eseri Temelinde Onun Nazım Teorisinde İhtiyâr Üslubunun Delaletleri Ve Mânânın Mânâsı}

\author{
Features Of The Methodology Of Choosing And The Meaning Of Meaning In The Theory Of \\ Systems According To Al-Jurjani In His Book (Dalail Al-I'jaz)
}

\author{
Mahmud Kaddum*
}

\begin{abstract}
This research seeks to study the methodology of choice and the meaning of meaning as appeared in the theory of systems in Al-Jarjani's book (Evidence of Miracles), to clarify the great impact the theory of systems has embedded in the manner of approach.

There have been many studies in the modern era that have made the approach between studying heritage and the new critical studies of theories and approaches. Versification theory, which Abd al-Qahir alJurjani (471 AH 1078- ) coined, is one of the theories those studies have addressed well. Since al-Jurjani has coined his theory in the fifth century, studies on this theory are in progress; however, studying versification theory in terms of the following two points (the selection and meaning of the meaning) needs further research. The research in hand comes to fill this research gag. The current research includes introduction, three chapters, and conclusion.
\end{abstract}

- The first chapter: the versification and its synonyms between al-Jurjani and the modern schools. versification.

- The second chapter: the selection in terms of Dalail Al-Ijaz and how the first relates to the versification.

- The third chapter: meaning of the meaning in terms of Dalail Al-Ijaz and how the first relates to the

- Conclusion: it shows the findings the author concluded.

In conclusion, the selection principle (according to al- Jurjani) relies on the language, which represents a treasury of the linguistic capabilities, which enables a speaker to translate words according to the status. Also, meaning of the meaning (according to al- Jurjani) is the main outcome al-Jurjani concluded by his theory in versification a speaker could use in more one way (e.g. metaphor, and metonymy).

\footnotetext{
* Dr. Öğr. Üyesi Bartın Üniversitesi, Edebiyat Fakültesi, Çeviribilim Bölümü Asst. Prof. Dr. Bartın University, Faculty of Letters, Department of Translation Studies ORCID 0000-0002-9636-4903

mkaddum@bartin.edu.tr
}

Cite as/ Atıf: Kaddum, M. (2020). ملامح أسلوبيّة الاختيار ومعنى المعنى في نظريَّة النَّم عند الجرجانيّ في كتابه (لالن الإعجاز) Cürcânî'nin "Delâilu'l-İ‘câz" adlı eseri temelinde onun nazım teorisinde ihtiyâr üslubunun delaletleri ve mananın manası Turkish Studies - Language, 15(2), 987-1003. https://dx.doi.org/10.29228/TurkishStudies.43399

Received/Geliş: 05 May/Mayıs 2020

Accepted/Kabul: 27 June/Haziran 2020

Copyright $(C)$ INTAC LTD, Turkey
Checked by plagiarism software Published/Yayın: 27 June/Haziran 2020 CC BY-NC 4.0 


\section{Structured Abstract: Approach}

The reader, who is a reviewer of modern linguistic and literary curricula, notes that there are similarities between these approaches and the work of Arab scholars in their linguistic and critical achievements, and the views of Abd al-Qahir al-Jurjani in systems, style, grammar and rhetoric are a model, as they have had a clear impact on the stylistic approach or what is known as "stylistic". This is indicated by studies and researches specialized in the study of Al-Jurjani writings, and the statement of their impact on modern sciences, whether structural, stylistic or modernist, and called for attention to the efforts of Al-Jurjani, says Abdel Moneim Talima that the modern stylistic lesson takes on the legacy of Abd al-Qahir rhetorical, and the Arab rhetorical heritage in general is a fundamental pillar. He called on Mohammed al-Ashmawi to adopt the approach of Abd al-Qahir, and promised him the way to revive rhetoric, saying: "If there is in the history of Arabic rhetoric what we cherish and encourage, and we call for his study, and we work to develop it, to suit our modern literary renaissance, it is Abd al-Qahir's approach in his study of rhetoric and his theory of systems, his way of understanding the language and its way of doing so, and his tasteful approach in analyzing texts, studying them and judging them." Mohammed Abdul Mutallab sees the possibility of adopting Abd al-Qahir's achievements as a successful tool "as a primary basis in the field of application, so that we do not lose sight of the stylistic achievements that are almost in line with the foundations on which Abd al-Qahir founded his studies ".

\section{Research methodology}

The appropriate approach to this research is the descriptive approach of the solution; Therefore, the approach taken in the course of this research will be: description-based analysis to reach the most accurate results.

\section{The conclusion}

-The study shows that talking about the theory of systems has references to Arab scholars - the pure and rhetorical - before Abd al-Qahir al-Jurjani, whose effort sought to lay the general foundations of the theory, and to talk about it in detail, and to develop special terms, the most important of which is the term "systems ."

-Grammatical and semantic aspects represent the basis on which linguistic theories are based, and this is evident in the theory of systems at Al-Jurjani when he searched for the meanings of grammar in the word, as well as in the levels of stylistic study.

-The study explained that the systems of Abd al-Qahir al-Jurjani were many of the pillars on which modern linguists, as well as modern critical schools, relied.

-There is a separation between the theory of systems of Al-Jurjani and the style of the the selection and the meaning of meaning;

-Abd al-Qahir al-Jurjani's principle of choice depends on the language that represents a safe of linguistic potential that enables the speech to be conducted in the form of denominator .

-The meaning of meaning in Abd al-Qahir al-Jurjani is the essential outcome of his theory of systems, which comes to the person speaking in more than one way, represented by the science of the statement, one of the three branches of Arabic eloquence, including( e.g. metaphor, and metonymy).

-The approach between heritage and modernity has a Sunni value for learners if they want to know how much has been overlooked, especially among the Arabic language.

-Ideas and theories in language, although different, often converge, as they are a cumulative human work that supports each other to reach the theoretical and practical foundations that govern language .

-Stylistic is one of the most important critical approaches that analyzes literary texts in an integrated way based on language, as it seeks the meaning of the word in the literary text written to monitor the elements of beauty and individuality in it.

Keywords: systems theory, the Selection, Meaning of the meaning, Dalail Al-I'jaz. 
Öz: Bu çalışma, Cürcânî'nin "Delâilu'l-i'câz" adlı eserinde üslup metotlarına olan büyük etkisini açıklamak üzere ele aldığı nazım teorisine uygun olarak 'ihtiyar üslubunun delaletleri'ni ve 'mananın manası'nı ele almaktadır. Modern çağda, geleneksel çalışmalar ile modern eleştirel çalışmaların ortaya koyduğu teori ve metotlar arasında karşılaştırma yapan çokça çalışma yapılmıştır. Temellerini Abdülkâhir el-Cürcânî’nin (ö. 471) ortaya attığı nazım teorisinin de yapılan çalışmalar açısından büyük bir payı olmuştur. el-Cürcânî’nin nazım teorisini ortaya koyduğu günden günümüze dek söz konusu teori hakkındaki okumalar birbirini takip edegelmiştir. Ancak söz konusu teorinin 'İhtiyâr İlkesi ve 'Mananın manası' mevzularıyla ilintili olan kısmı 1şık tutulmaya muhtaç vaziyettedir. İşte bu çalışma da söz konusu meselenin araştırılıp kuşatılmasının bir ürünüdür. Çalışma, mukaddime, üç bölüm ve bir sonuçtan oluşmakta olup şu şekildedir:

Birinci bölüm: el-Cürcânî ve çağdaş alimlere göre 'nazm' kelimesi ve eş anlamlıları

İkinci bölüm: Delâilu'l-i'câz'da ihtiyâr ilkesi ve nazım teorisiyle alakası

Üçüncü bölüm: Delâilu'l-i'câz'da mananın manası ve nazım teorisiyle alakası

Sonuç: Araştırmacının ulaştığı en önemli sonuçlara bir bakış

İşte bu çalışma bu teorideki ihtiyâr üslubunun delaletlerini ve mananın manasını ele almaktadır. Çalışmada açıklığa kavuştuğu üzere Abdülkâhir el- Cürcânî’nin nezdinde 'ihtiyâr ilkesi' dilsel imkanları içeren bir hazineyi temsil eden lügati ifade etmektedir ve bu lügat mütekellime konuşmasını makama uygun bir şekilde gerçekleştirmesini sağlamaktadır. Yine onun nezdinde 'mananın manası', onun nazım teorisiyle kendisine ulaşılan öz mahsulü ifade etmektedir ve mütekellim nezdinde mecaz, istiare ve kinaye gibi birçok farklı yoldan meydana gelmektedir.

Anahtar Kelimeler: Nazım Teorisi, İhtiyâr, Mananın manası, Delâilu’l- i‘câz.

\section{ملامح أسلوبيّة الاختيار ومعنى المعنى في نظريَّة النَّلم عند الجرجانيّ في كتابه (دلانل الإعجاز)}
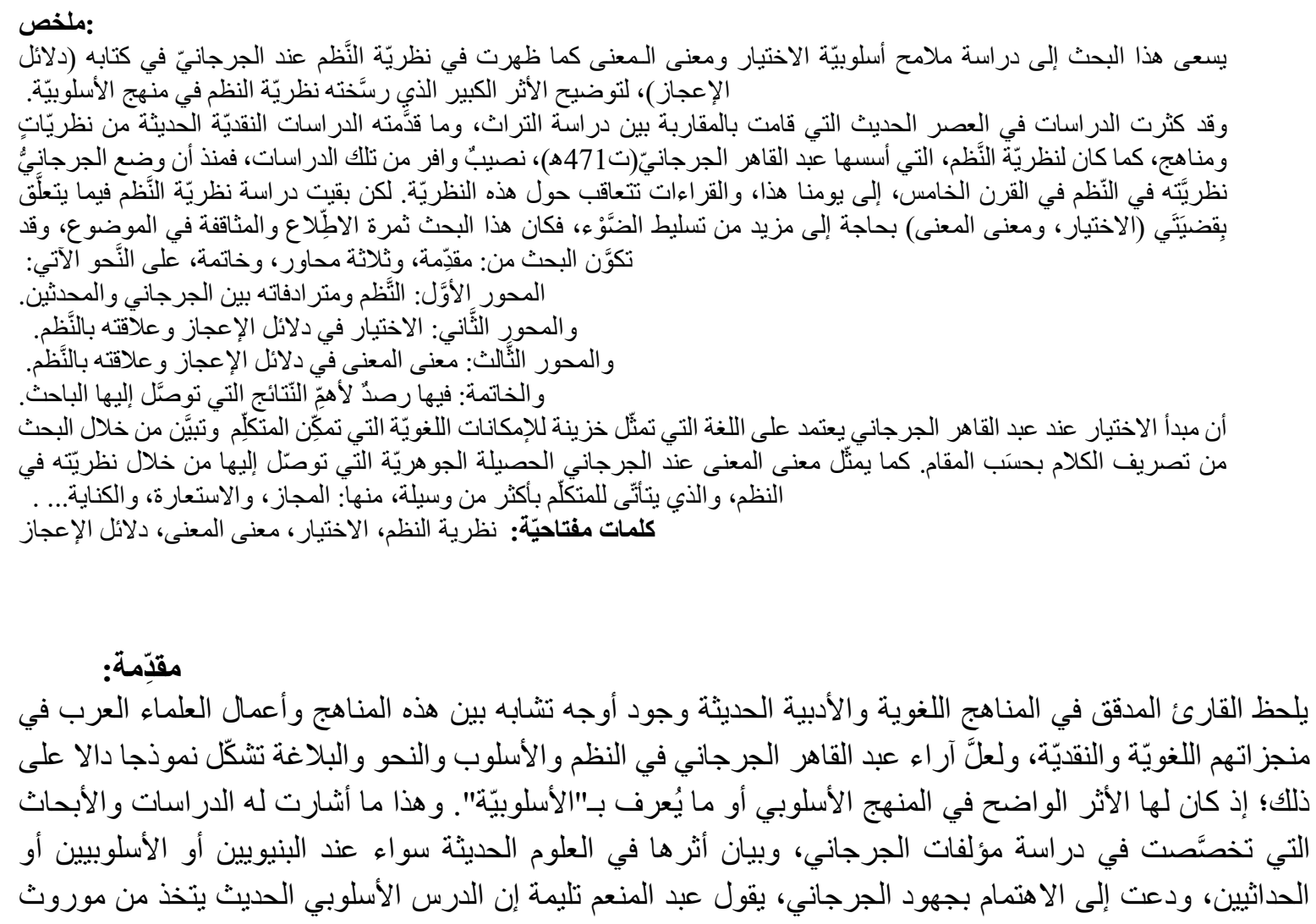


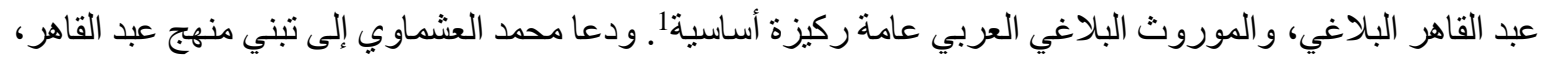

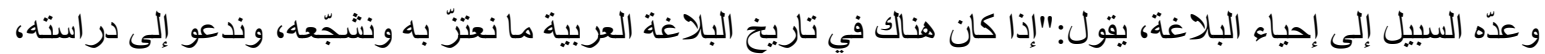

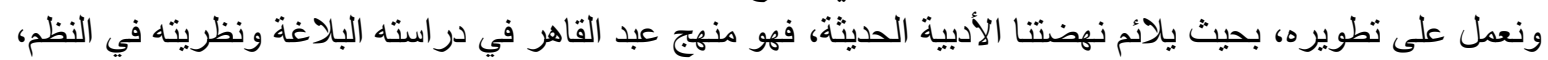

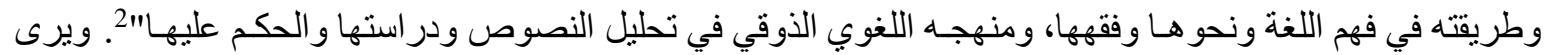

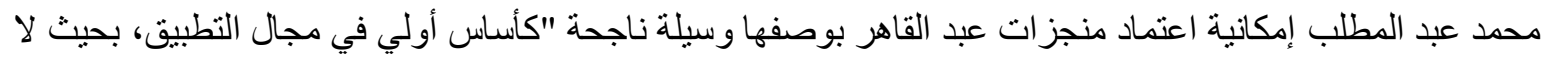
تغيب عنا المنجزات الأسلوبية الو افدة التي تكاد تتو افق في أسسها العامة مع الأسس التي أقام عليها عبد القاهر در استها"

المحور الأول: التَّظم ومتر ادفاته بين الجرجاني والمحدثين

أوَّاًا: عبد القاهر الجرجانيّ، ونظريَّته في النَّظم:

هو " عبد القاهر بن عبد الرحمن بن محمد الجرجاني الإمام النحوي المتكلم، واضع أسس البلاغة، و المُشُبّيّ لأركانها،

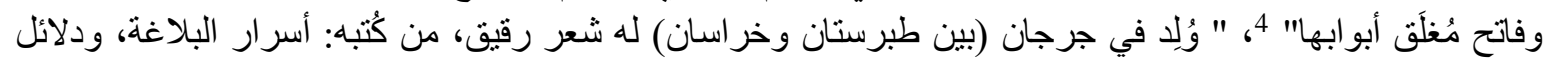

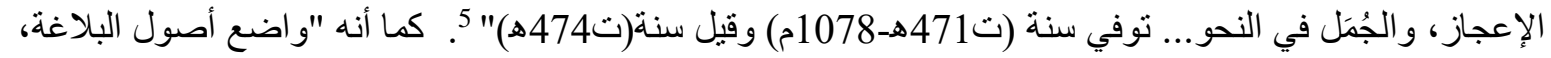

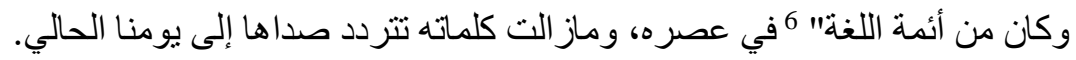

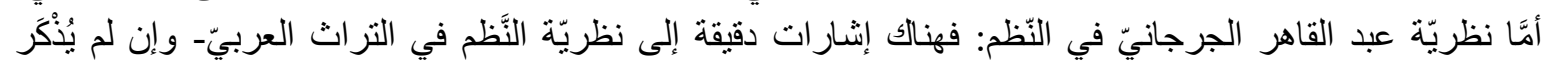

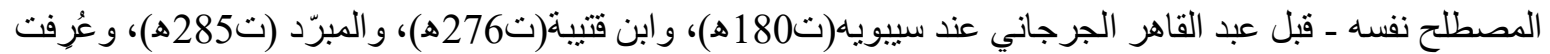
في القرن الر ابع عند أبي هاثم الجبّائي(ت

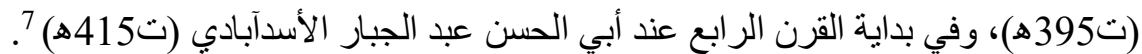

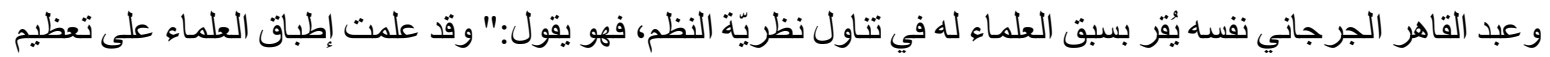

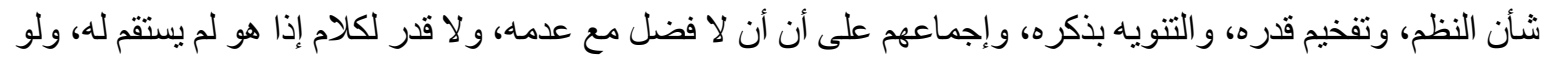

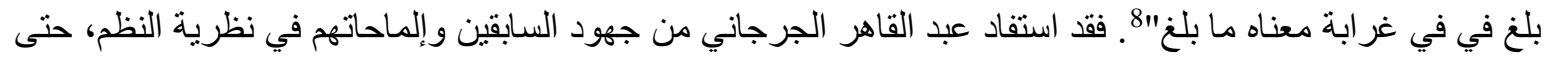

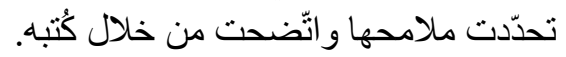

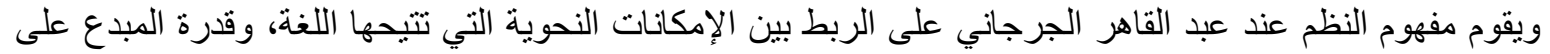

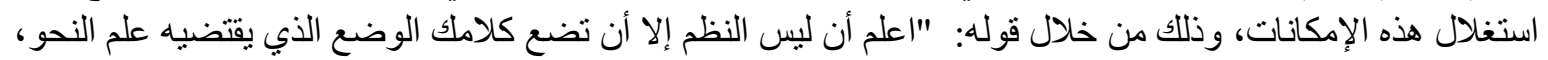

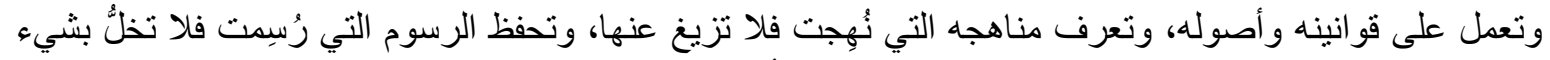

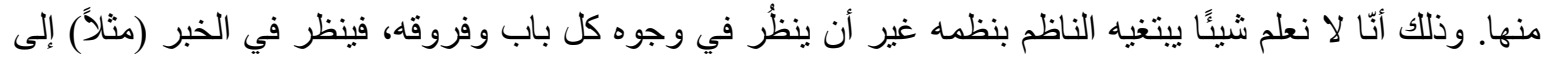

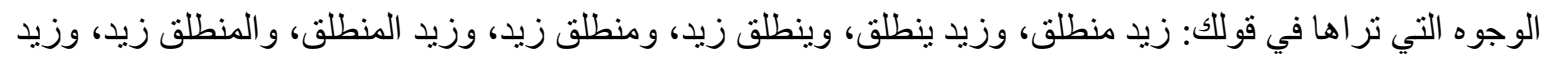

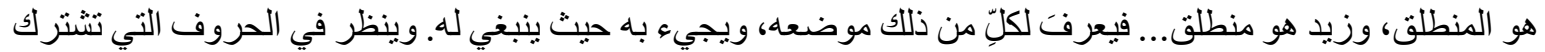

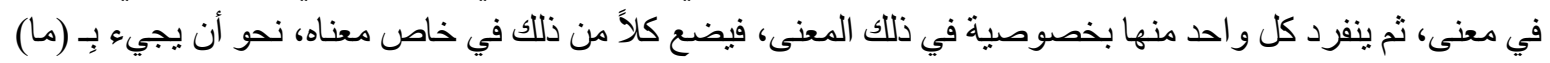

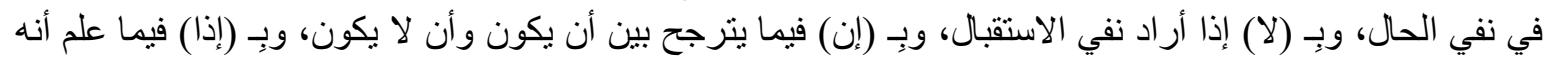

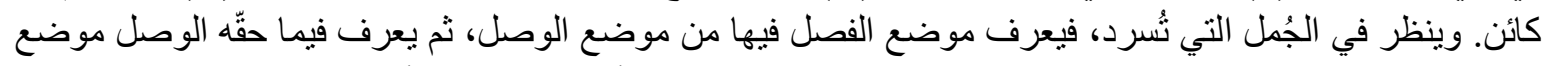

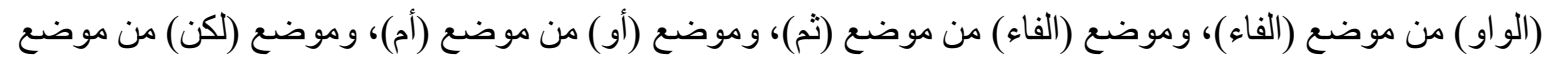

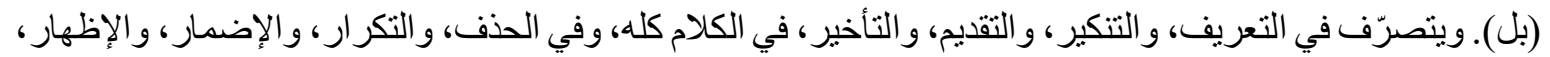

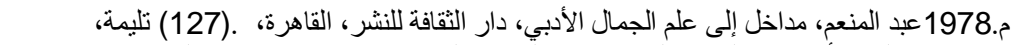

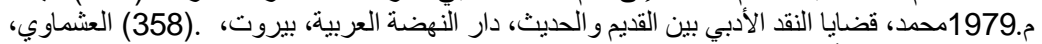

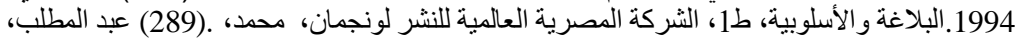

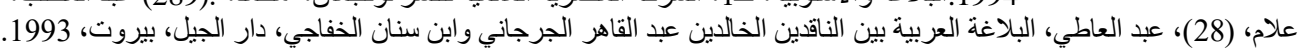

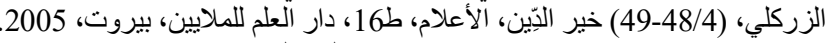

الزركلي، (48/4-49) مرجع سابن.

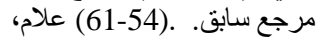

عبد القاهر ، قر أه و علّق عليه محمود محمد شاكر، ط3، مطبعة المدني، القاهرة، ودار المدني، جدة، 1992. 


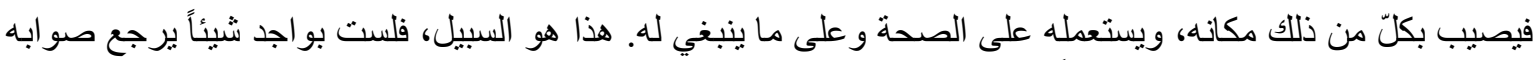

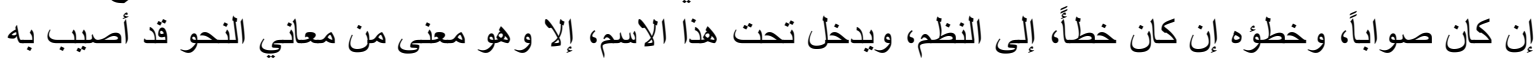

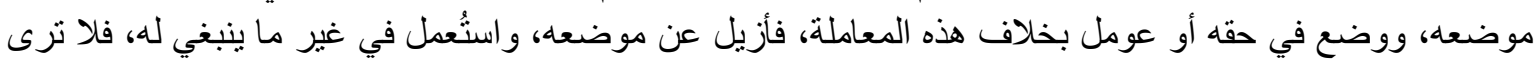

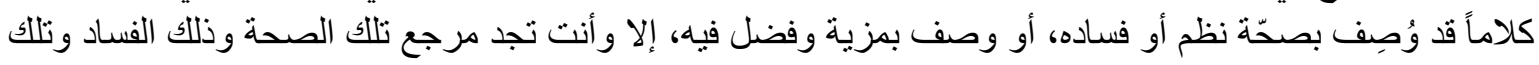

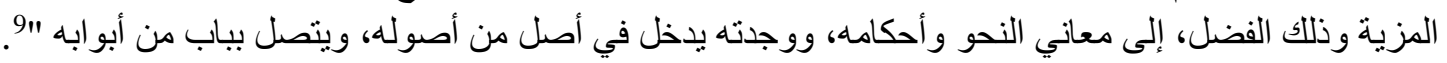

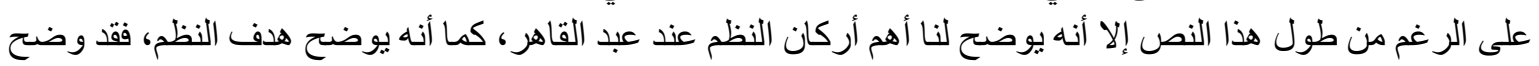

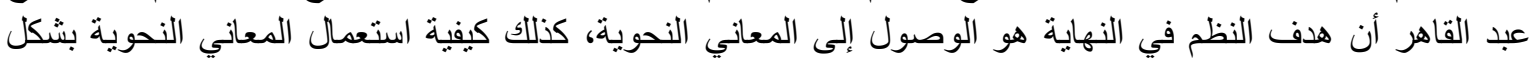

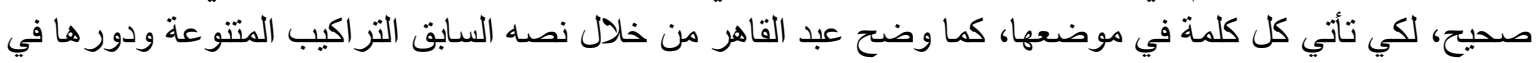
بناء الجملة

ذلك هو تصور عبد القاهر الجرجاني لكيفية تطبيق نظرية النظم، وتتفيذه في واقع الاستعمال اللُّوي، فهو يضع الكلام

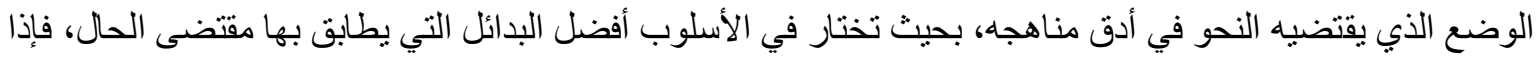

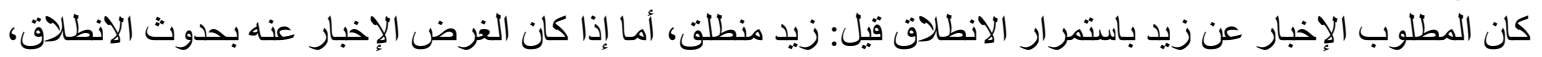

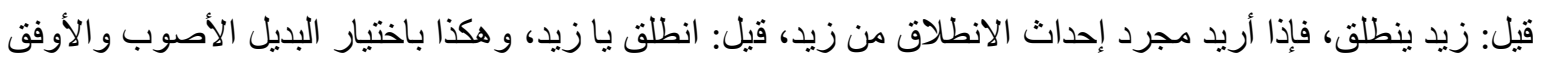

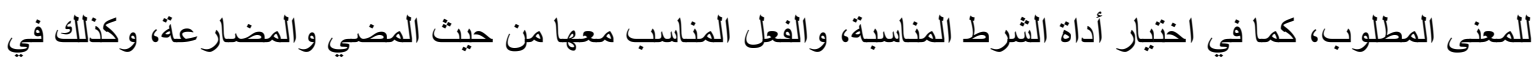

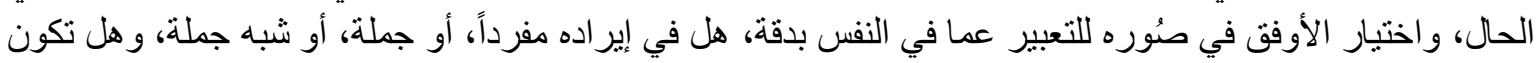

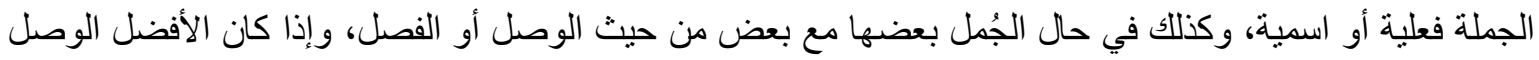

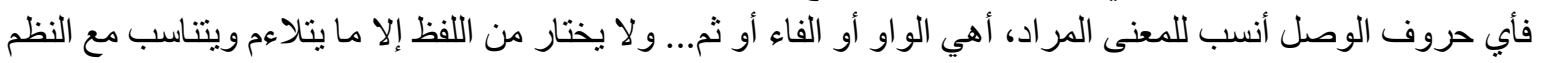

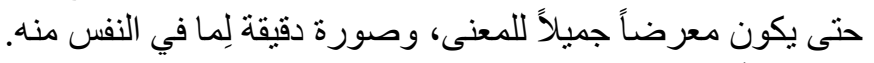

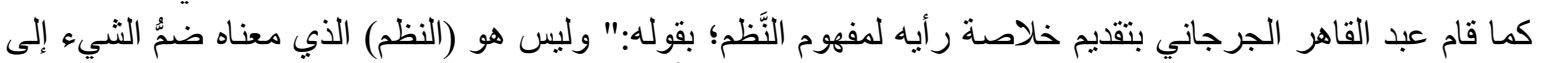

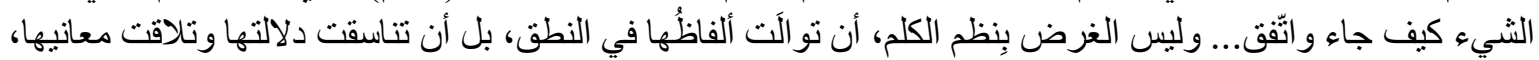

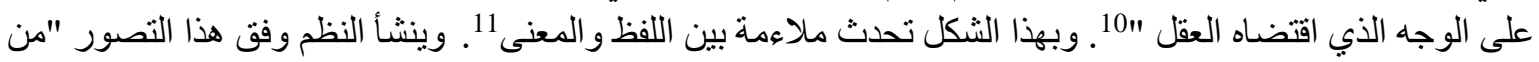

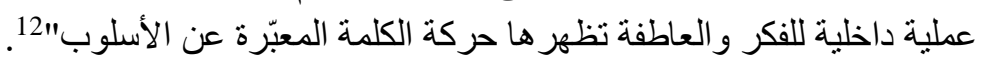

\section{ثناتيًا: الأسلوبيّة:}

يقوم المنهج الأسلوبي على الاهتمام بالجوانب اللغوية واللسانية للنصوص، ويسعى إلى إبراز الملامح الأسلوبية التي الإيلية

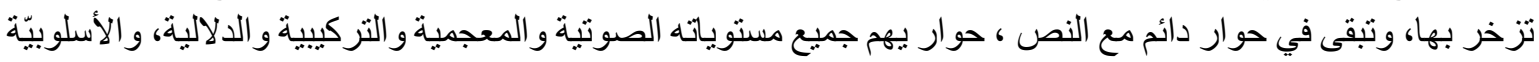

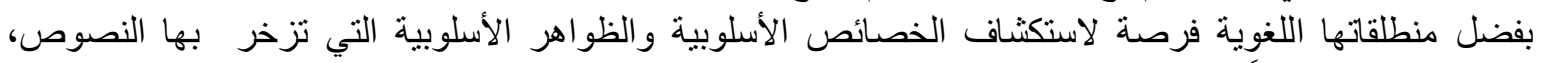

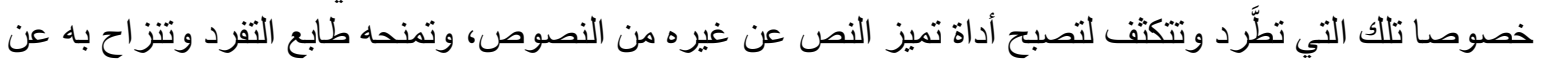

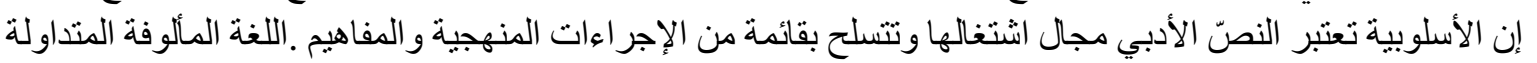

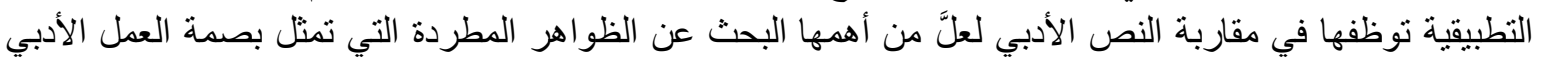

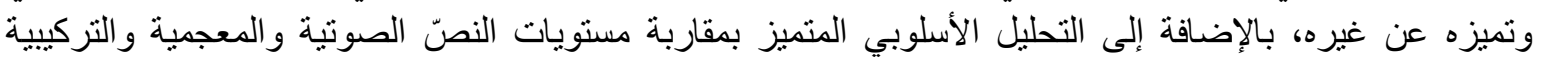

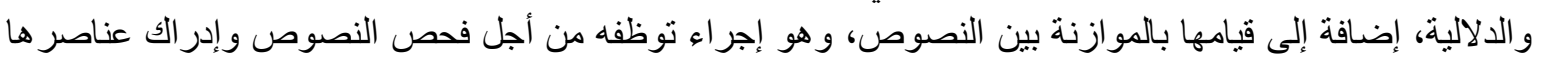

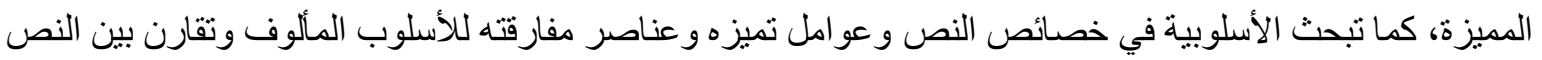

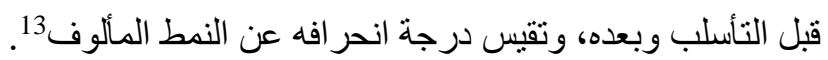

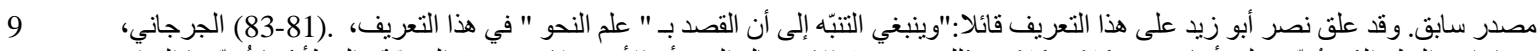

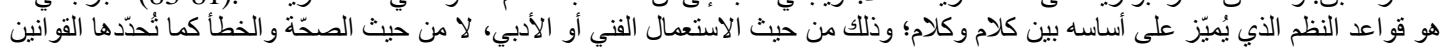

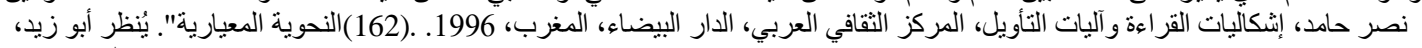
مصدر سابق. . (50-49) الجرجاني،

Kadir KINAR (75-73). ,Abdulkahir El-cürcânî’nin Nazm teorisi, Sakarya Üniversitesi Ilahiyat Fakültesi Dergisi 13 / 2006.

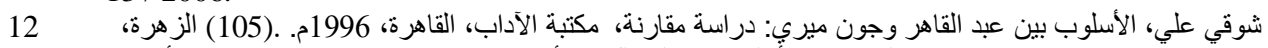

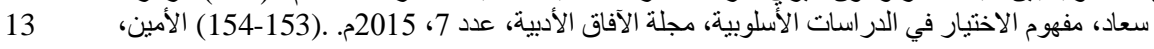


وقد تعدّدت مفاهيم الأسلوبية، ولعلّ من أبرز مفاهيمها، أنّها:" علم لغوي حديث يبحث في الوسائل اللغوية التي تُكسبب

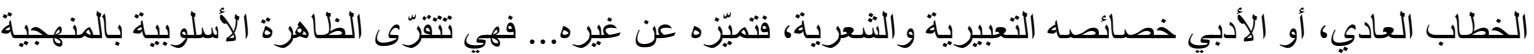

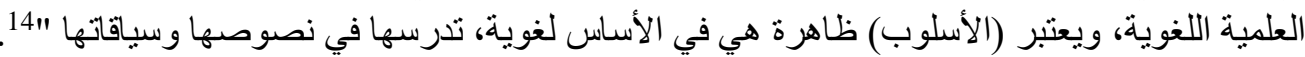

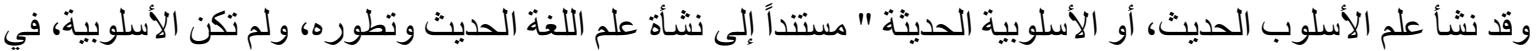

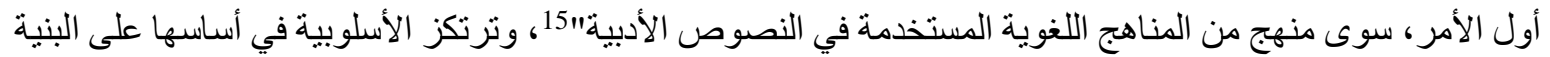

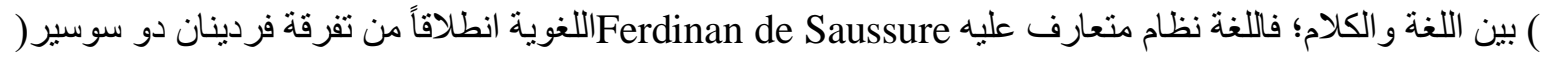

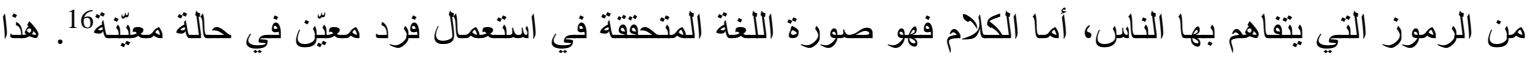

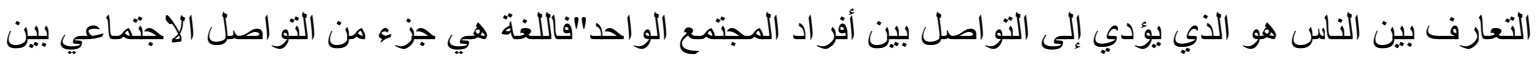

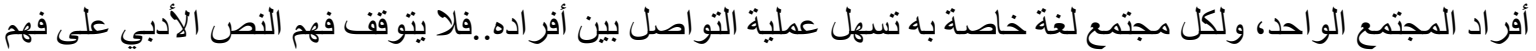

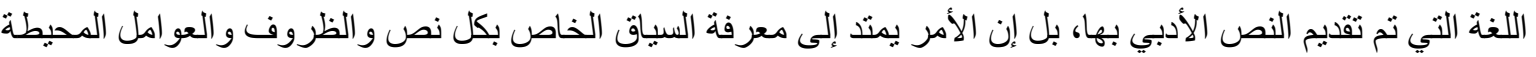

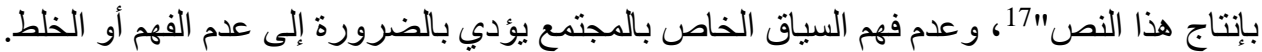

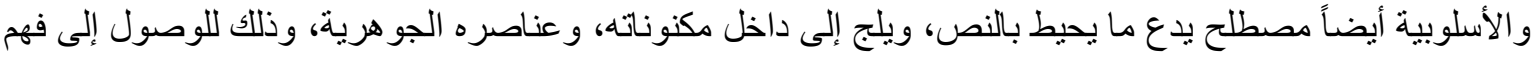

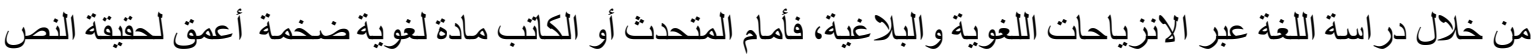

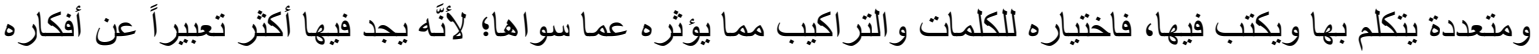

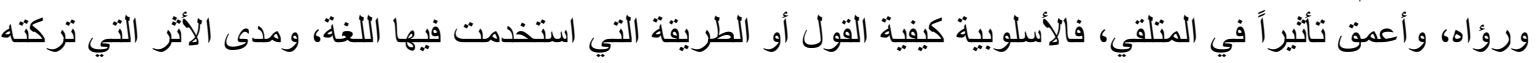

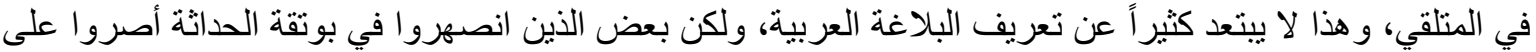

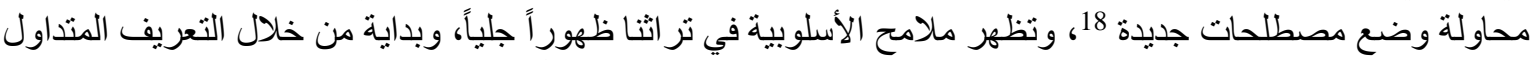

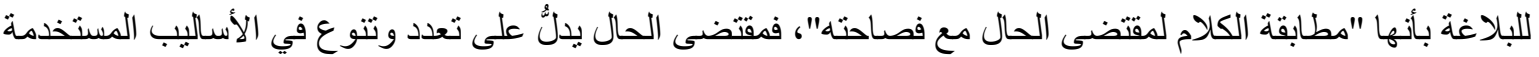

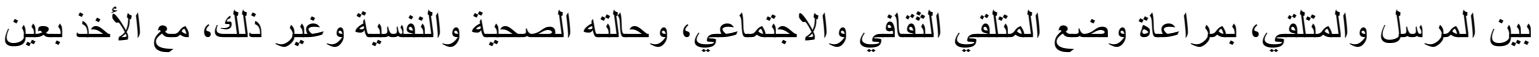

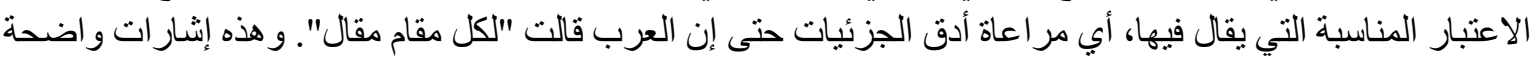

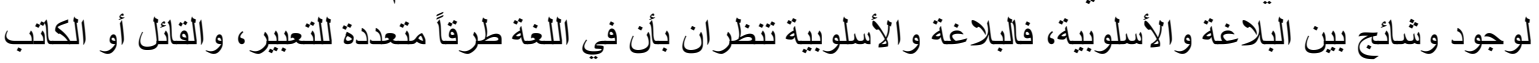

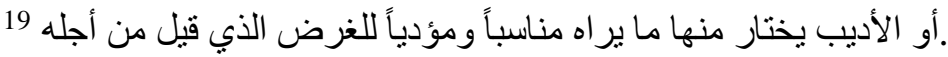

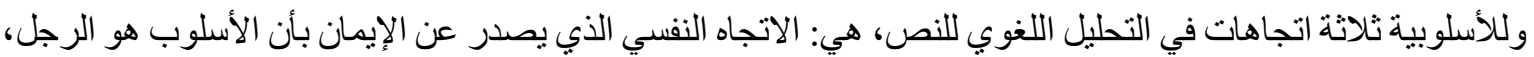

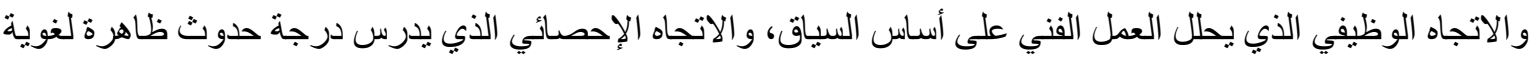

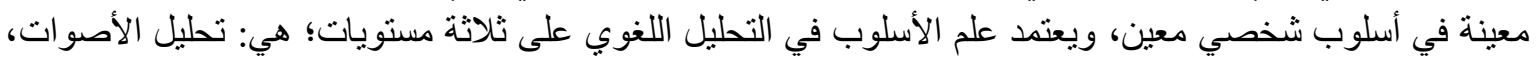
وتحليل التركيب، وتحليل الألفاظ20

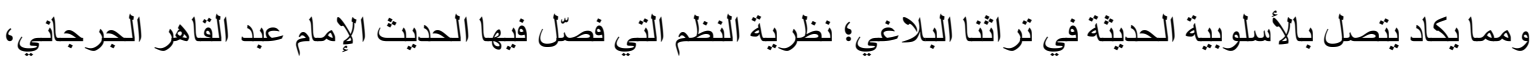

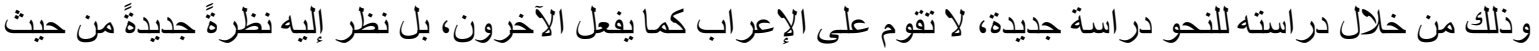

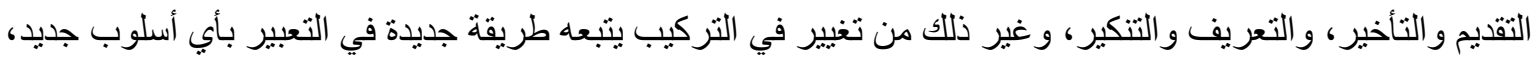

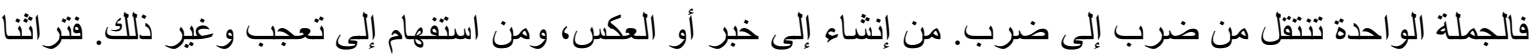

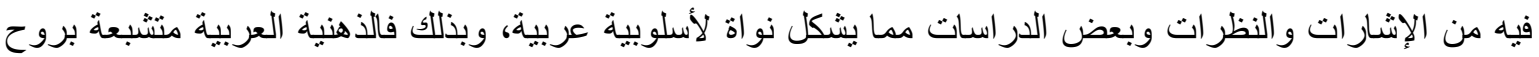

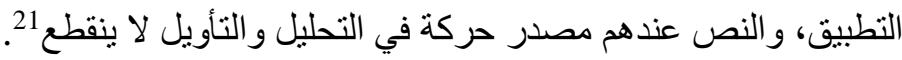

يقول المسدي: إن الناظر في الأسلوبية إجمالاً منذ نشأتها إلى آخر مطاف تطور ها في العصر الحديث يقق على حقيقتين اثتتين: أو لاهما أن علم الأسلوب من حيث هو معرفة إنسانية قديم في تصور اته المبدئية، حديث في بلورة غائها فياته وتشكيل

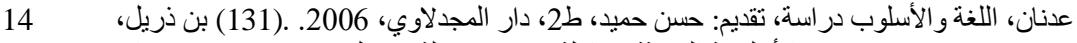

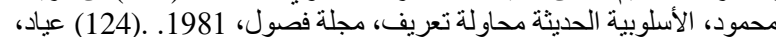

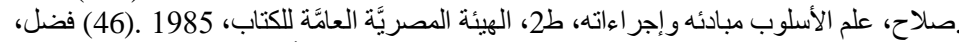

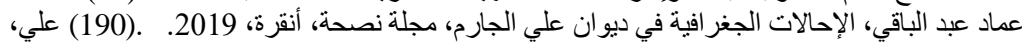

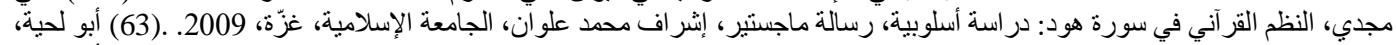

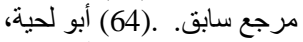

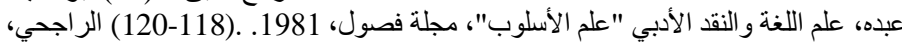

مرجع سابق. .68-67-67) أبو لحية، 
مناهجه، وثانيتهما أنَّهه علم ما فتئ يتطور جذرياً غير أنَّ الحدود الزمنية بين تحو لاته مائعة جداً"22. والأسلوبية بإز التها

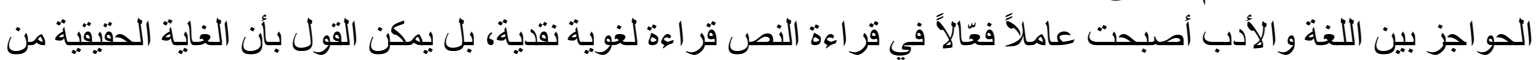

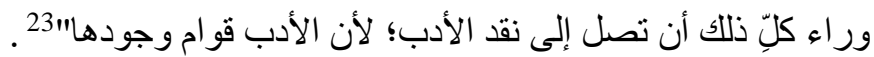

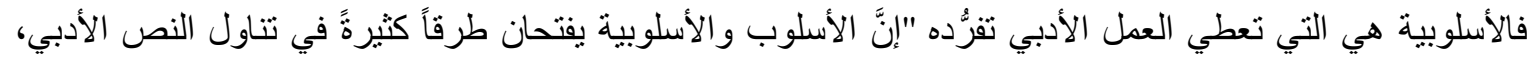

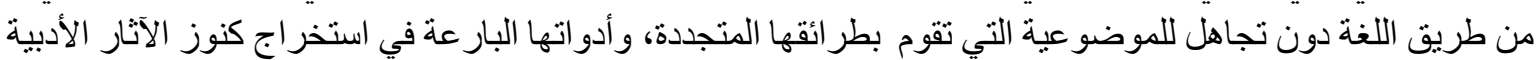

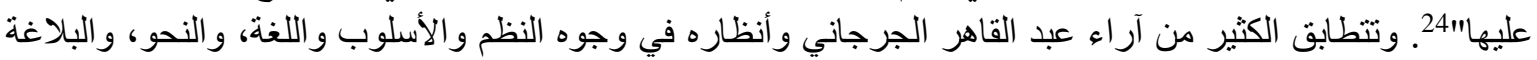

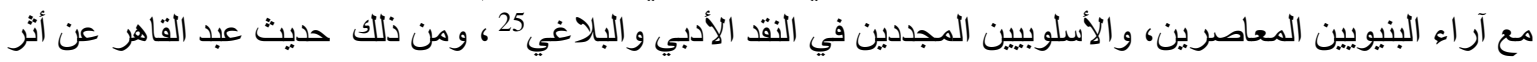

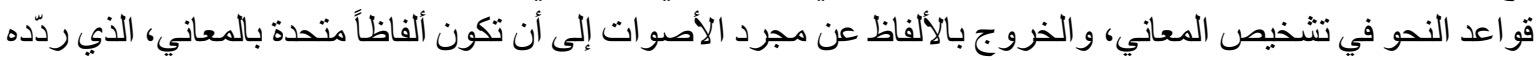

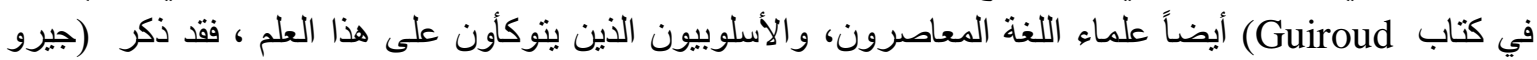

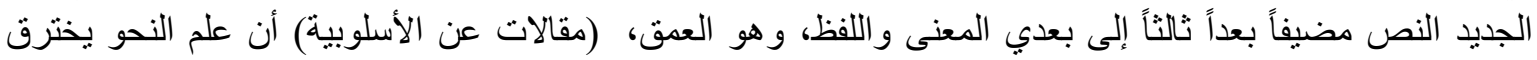

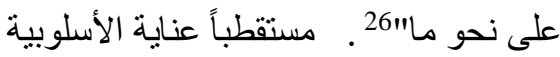

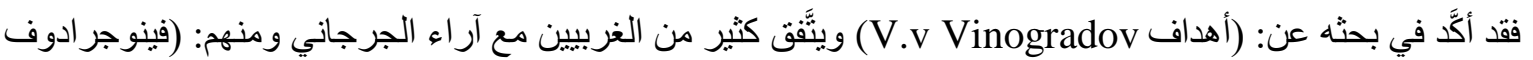

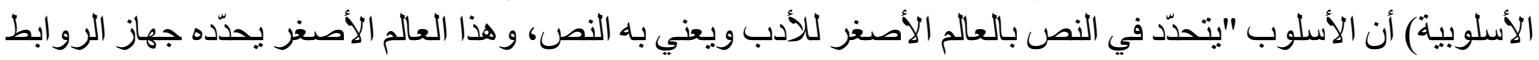

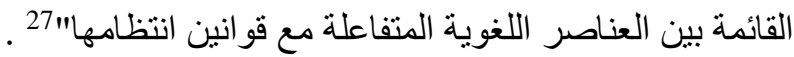

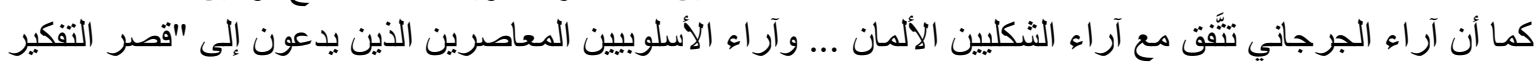

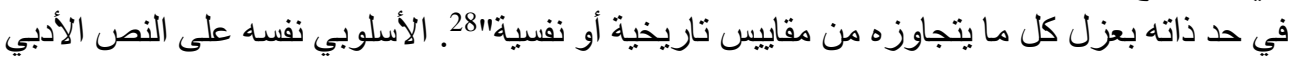

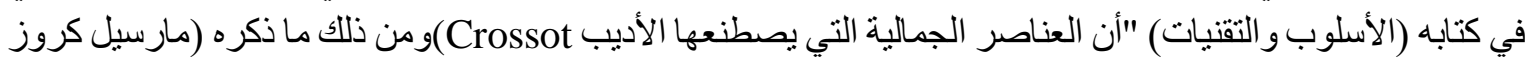

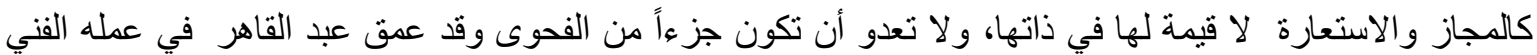

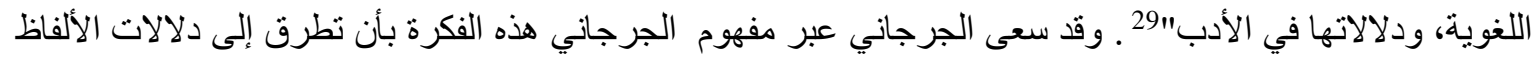

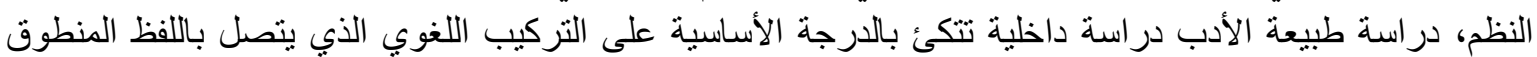

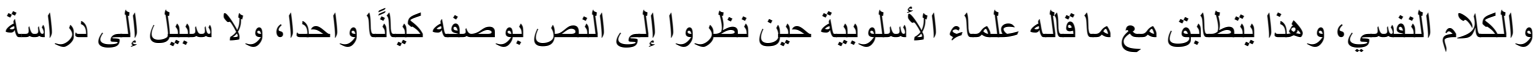
العمل الأدبي إلا على أساس التمازج الكامل بين عناصره مع التنبيه إلى أهمية المخاطب في عملية الإبداعُ30.

\section{المحور الثَّاني: الاختيار في دلائل الإعجاز و علاقته بالنَّظم}

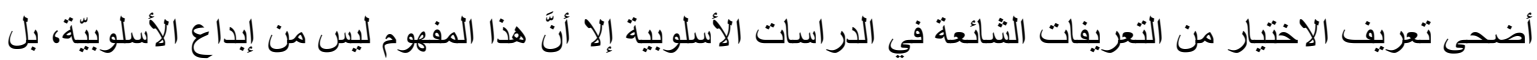

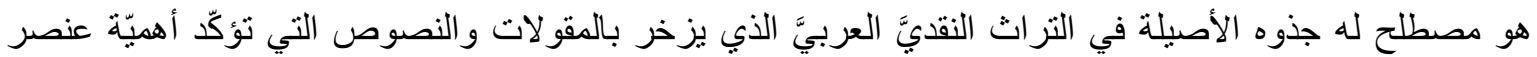

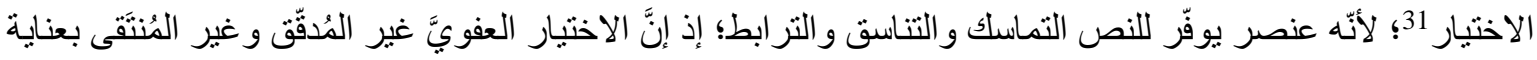

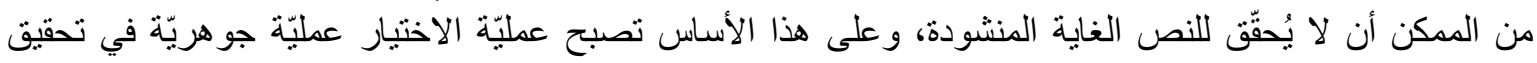

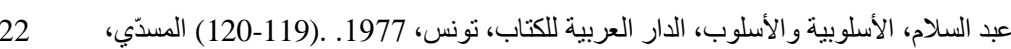

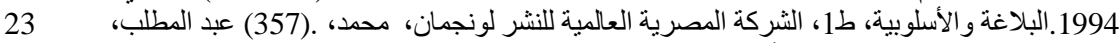

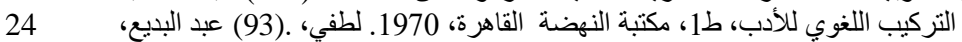

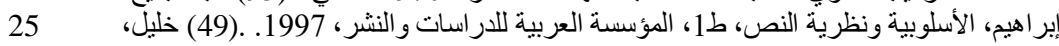

مرجع سابق. . (51) المسدّي، 26

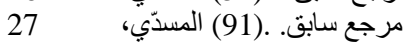

مرجع سابق. والجرجاني، (206)، مصدر سابق. . (51) المسدّي،

مرجع سابق. .(49) خليل،

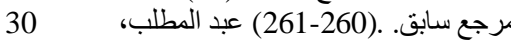

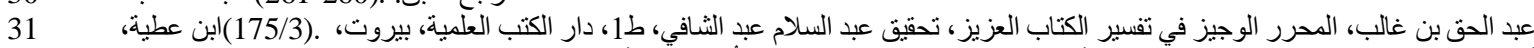

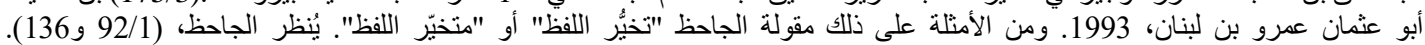

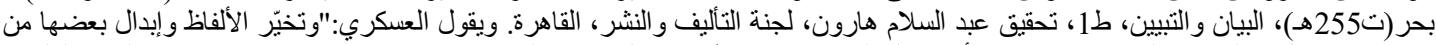

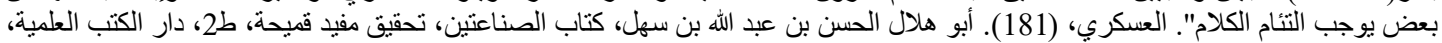
بيروت، 1984م. 
عنصري الفَهم والإفهام، الذي هو لبُّ البلاغة القديمة، وجوهر عمليّة التلقّي في الدراسات الحديثة التي تتصّل بعلم

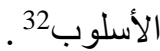

وقد فطن عبد القاهر الجرجاني إلى أهميّة عنصر الاختيار وتفاوت المبدعين في أساليبهم، وكأنّه يؤكّد أنَّ عمليّة الاختبار

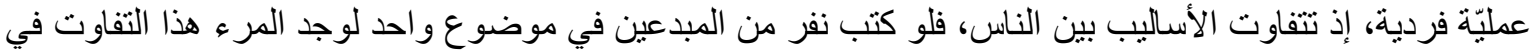

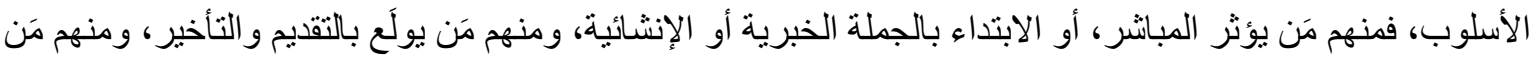

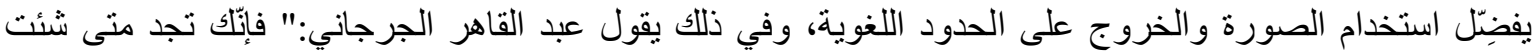

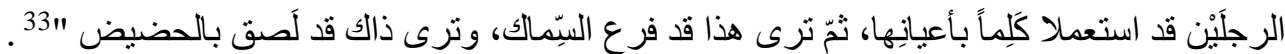

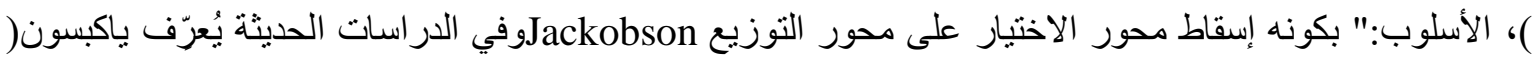
؛ فالمنشئ choice "34. فاختيار الكلمات يتوقّف على توزيعها، "وشاع في الدراسات الأسلوبية أن الأسلوب اختيار

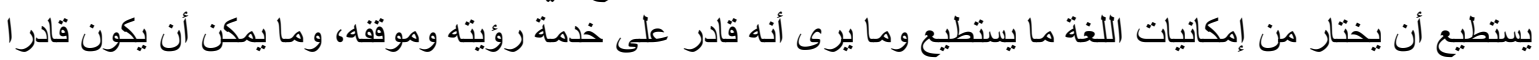

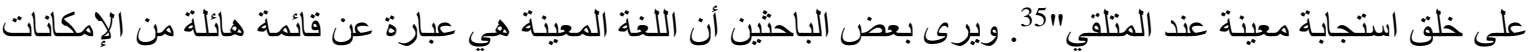

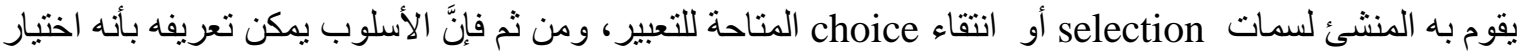

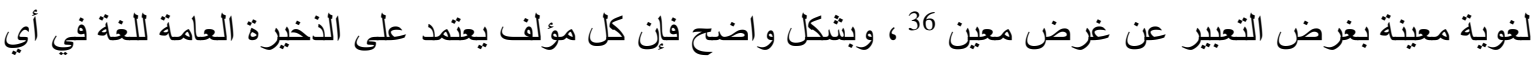

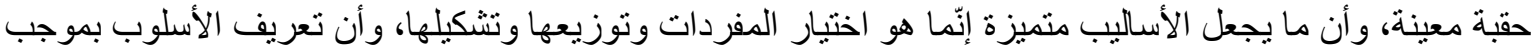

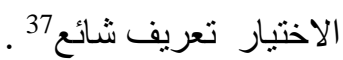

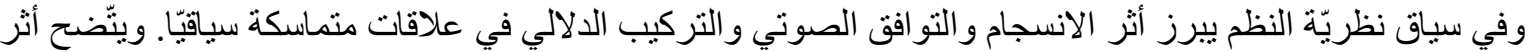

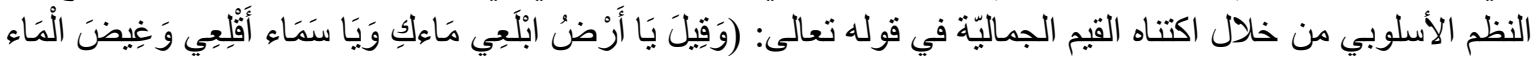

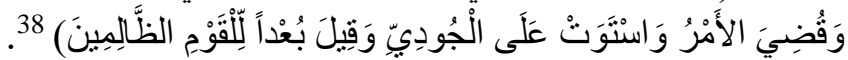

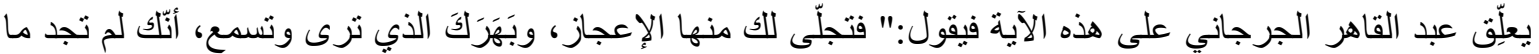

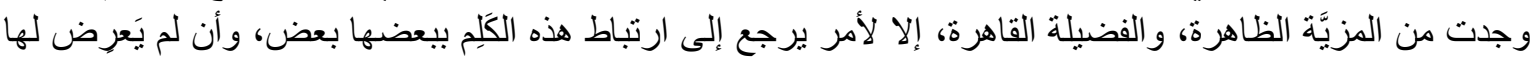

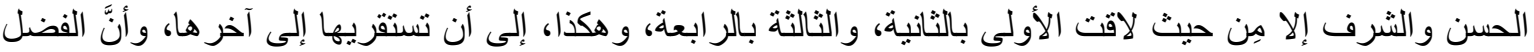

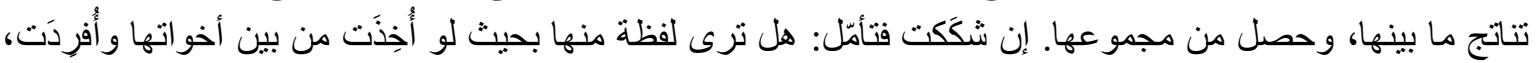

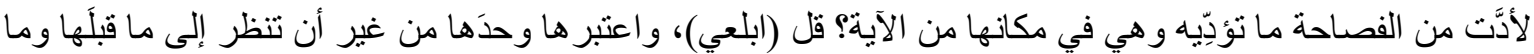

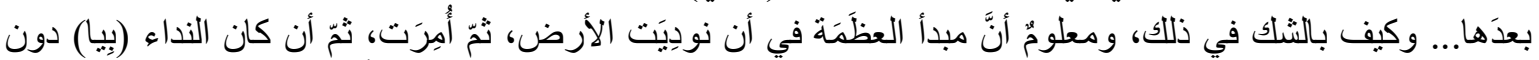

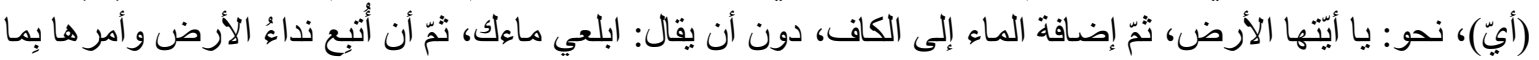

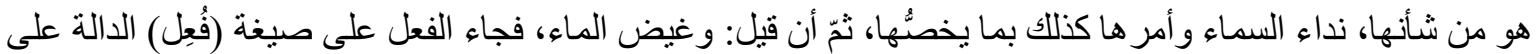

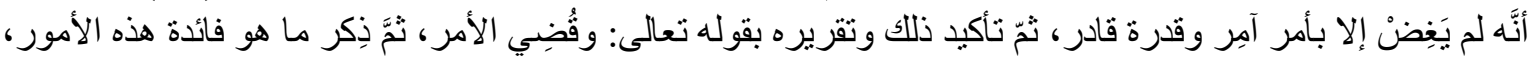

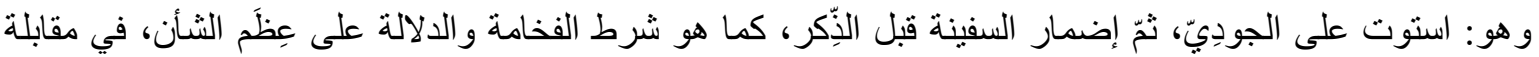

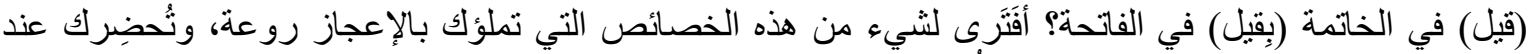

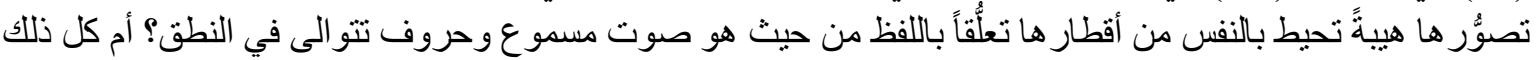

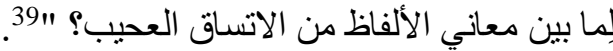

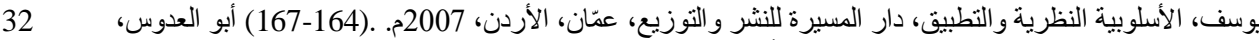

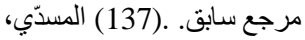

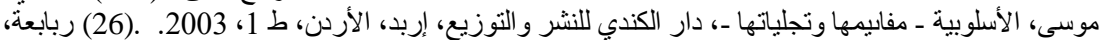

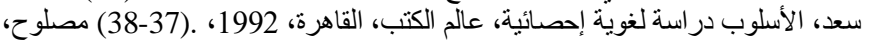

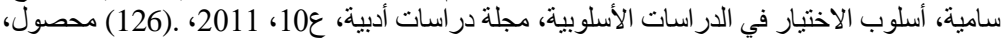

سورة هود، آية (44). (44).

مصدر سابق. .47-47) الجرجاني، 
و استناداً على ما أورده عبد القاهر الجرجاني في دلائله:" و لا يكفي أن تقولوا: إنَّه خصوصيَّةُةٌ في كيفيَّة النظم، وطريقة

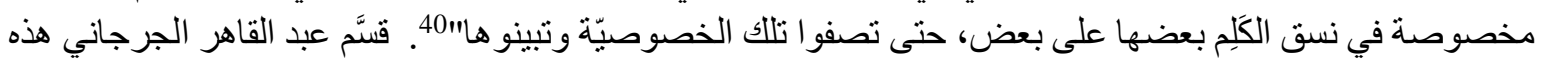
الآية إلى خمسة أقسام على النحو الآتي:

1- (قيل يا أرض ابلعي ماءَك).

2- 2 (ويا سماء أقلعي).

3- (وغِيض الماءء).

4- (وقيل بعداً للقوم الظالمين). (وثيض)

5- (وقُضِي الأمر واستوت على الجودِي).

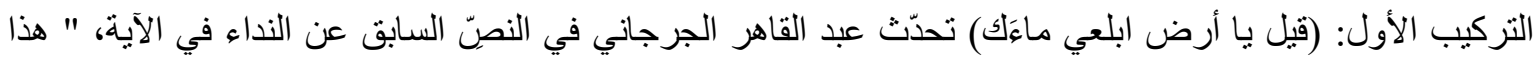

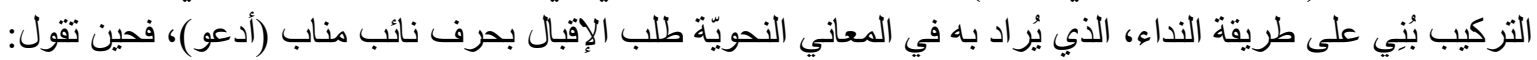

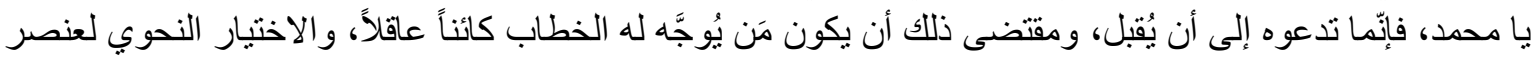

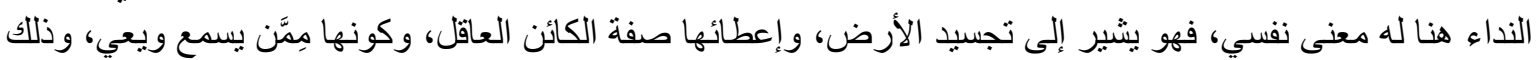

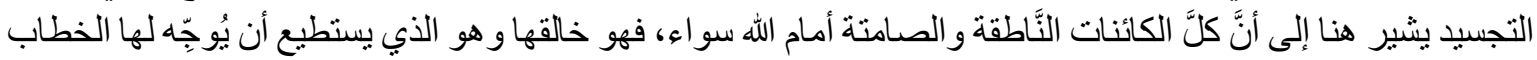

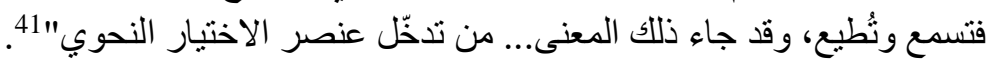

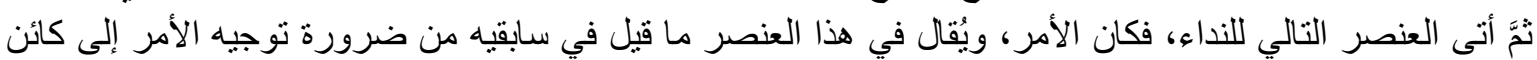

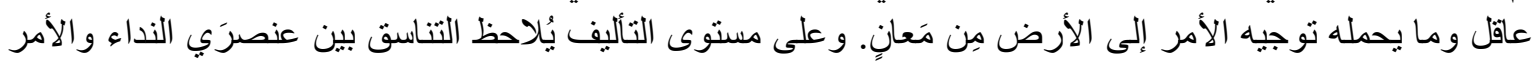

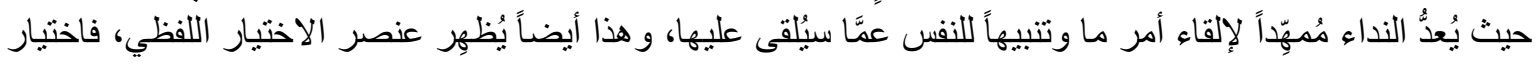

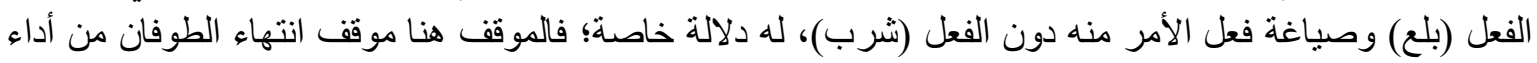

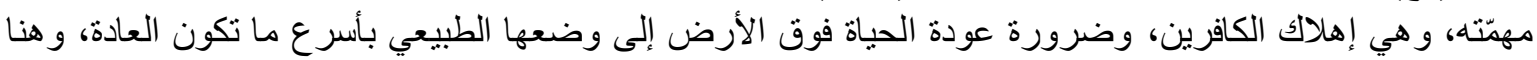

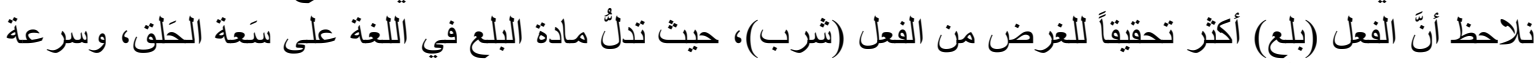

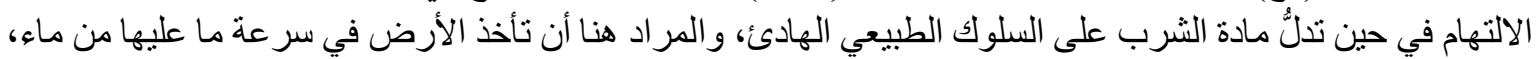

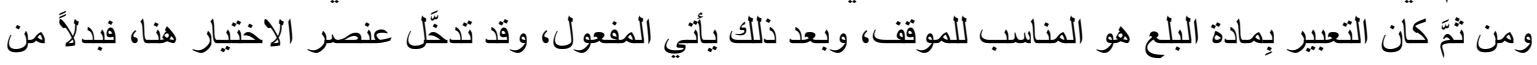

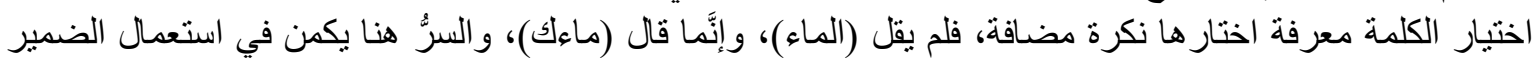

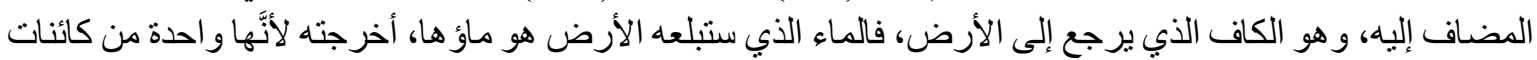

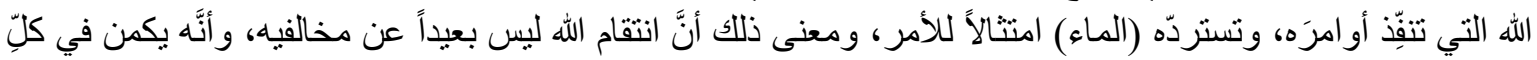

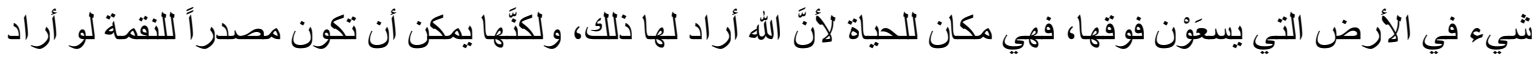

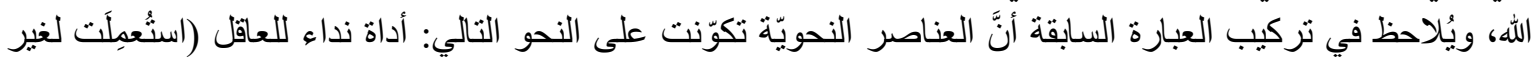

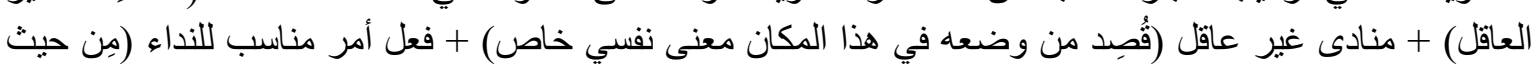

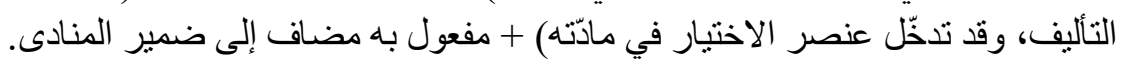

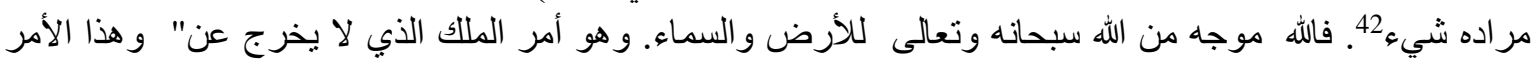

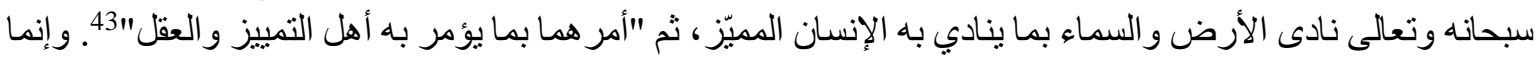

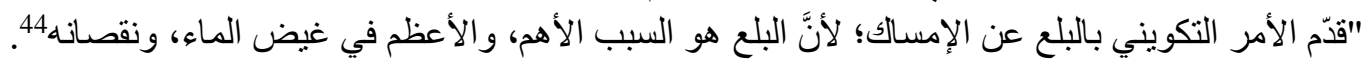

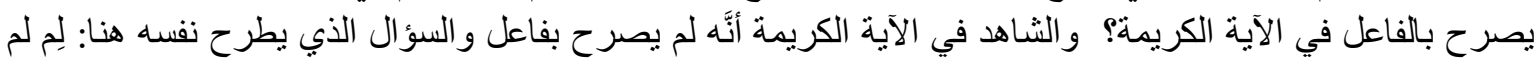

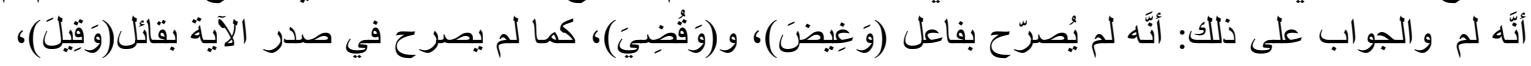

مصدر سابق. . (36) الجرجاني،

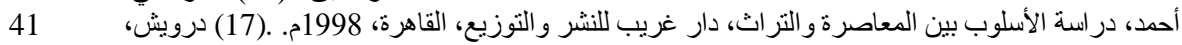

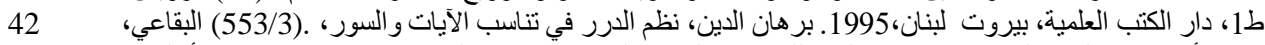

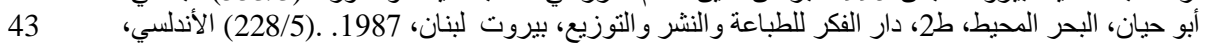

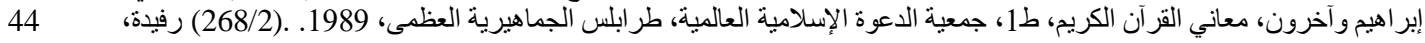


وقو عها إلا من قادر لا يصر ح بفاعل وكذا لم يصرح بمن سوَّى السفينة؛ تنبيهاً على أن تلاك الأمور العظام لا يتصور

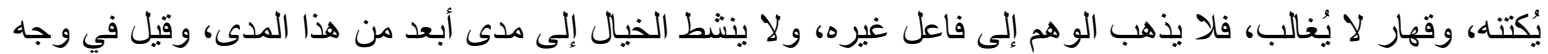

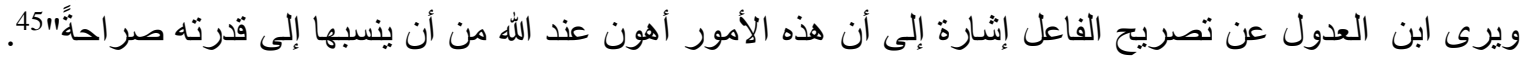

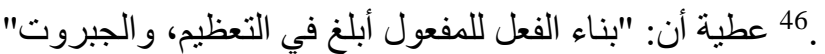

التركيب الثاني مِن الآية:(ويا سماء أقلعي)، ويقارب بينه وبين التركيب الأوّل:(قيل يا أرض ابلعي ماءَك)، ويجد مشابة

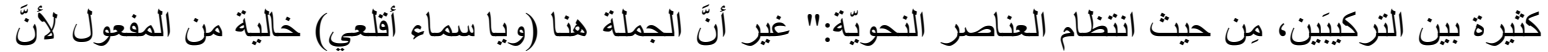

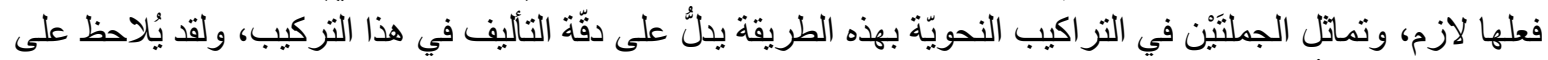

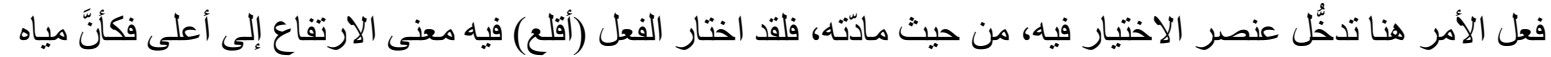

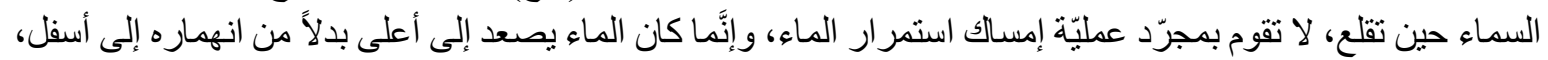

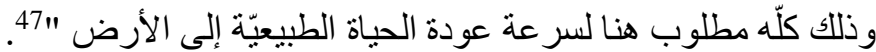

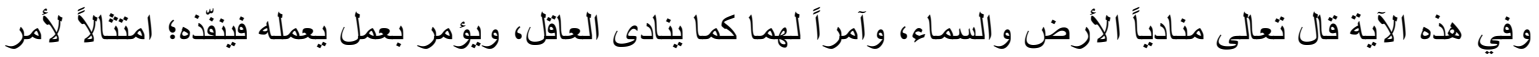

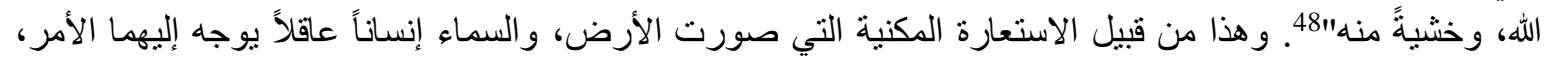

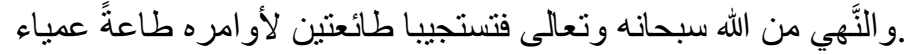

ثم يأتي التركيب الثالث في الآية (وغِيض الماء)، و عنصر الاختبار هنا جاء في إيثار صيغة على أخرى، فهنالك صنياء

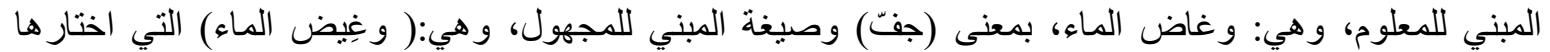

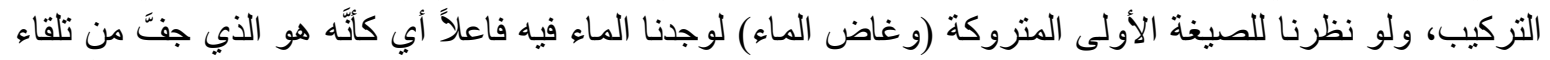

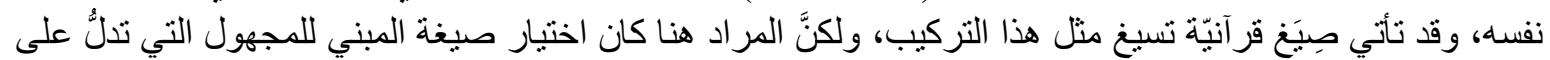

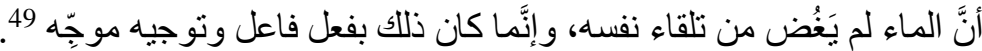

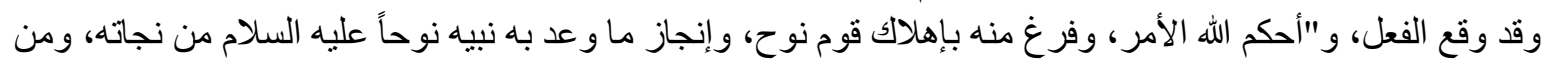

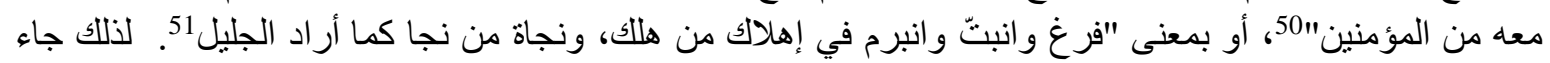

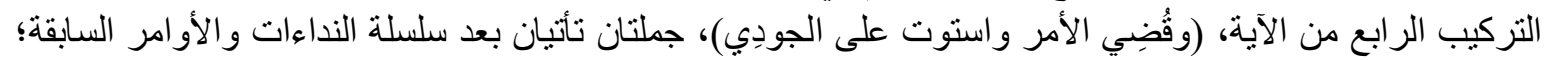

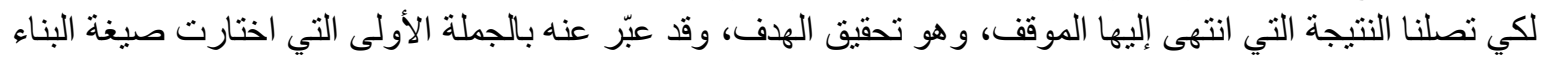

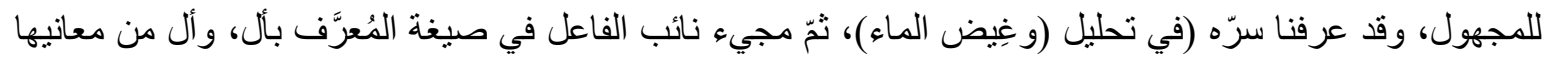

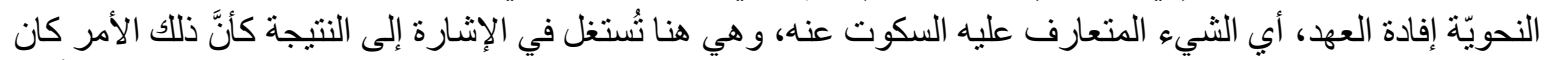

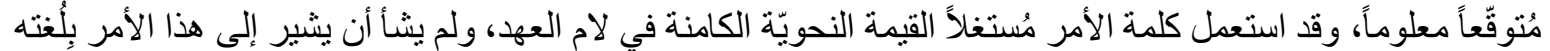

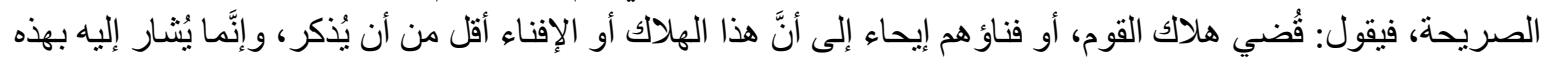

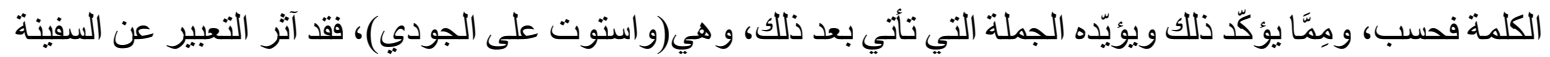

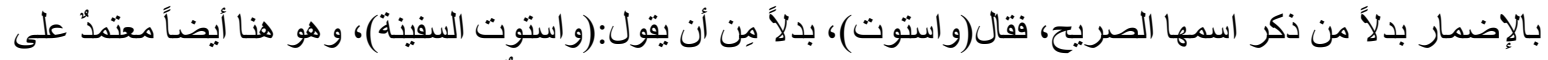

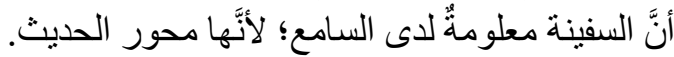

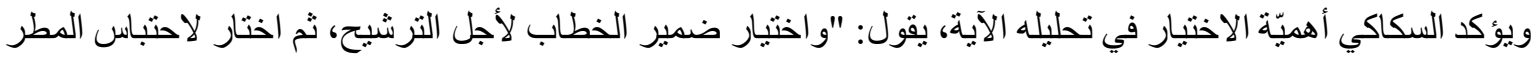

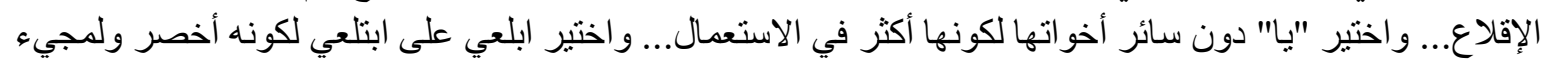

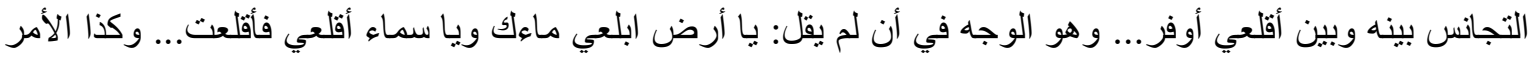

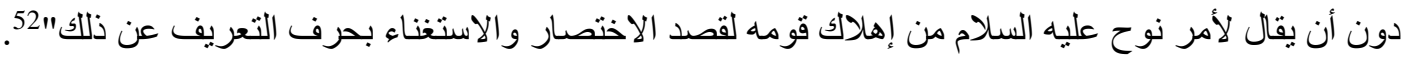

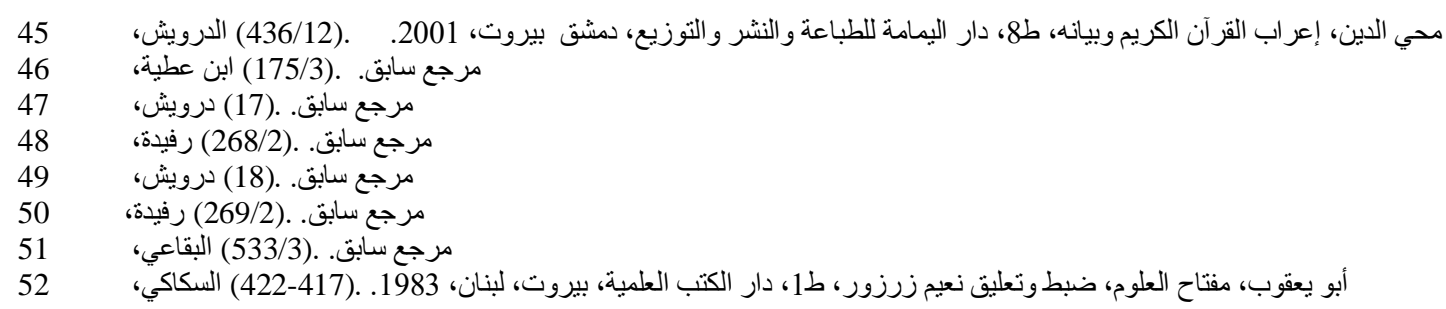


ولعلَّه من الأهميَّة بِمكان -بعد در اسة مثال عن مبدأ الاختيار - الحديث عن اهتمام عبد القاهر الجرجاني بمبدأ الاختيار

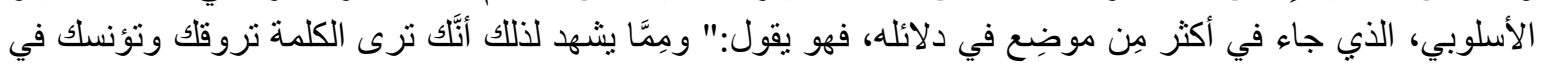

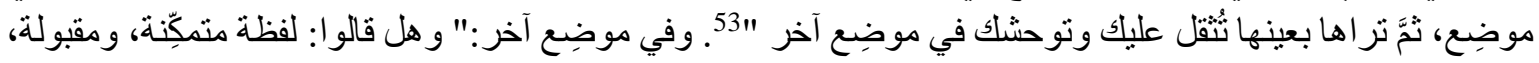

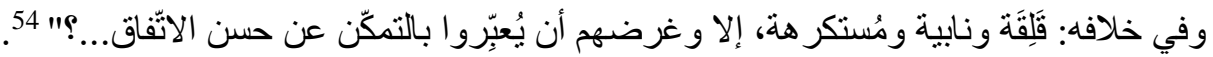

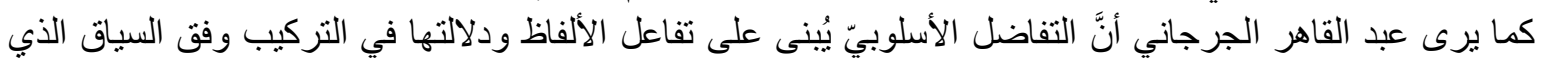

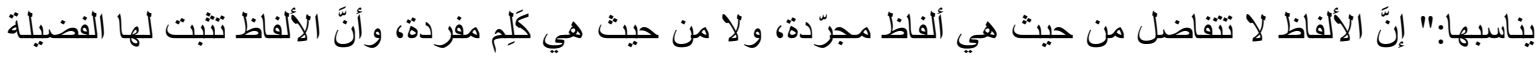

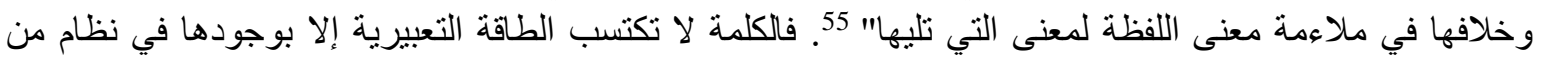

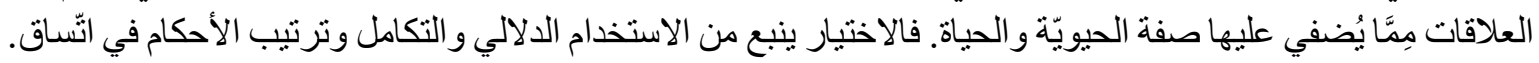

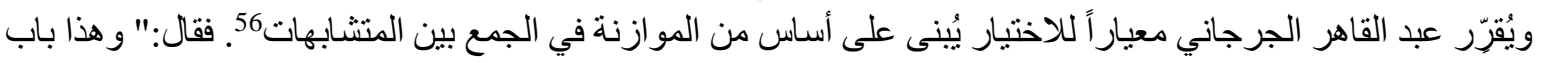

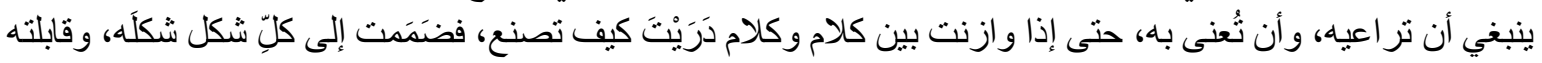

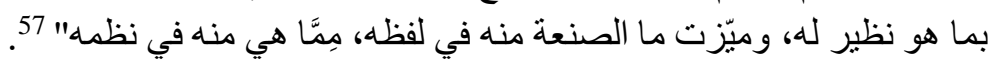

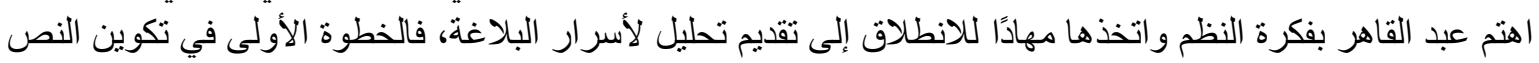

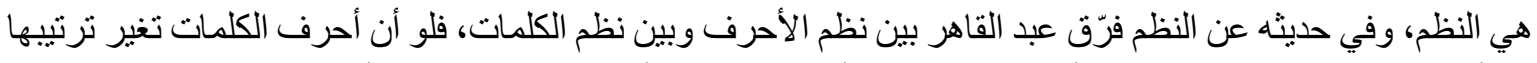

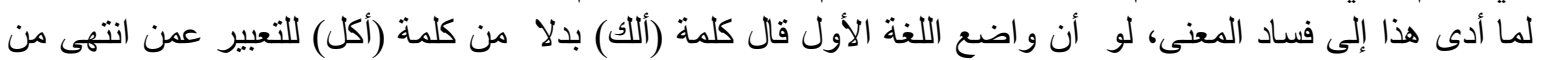

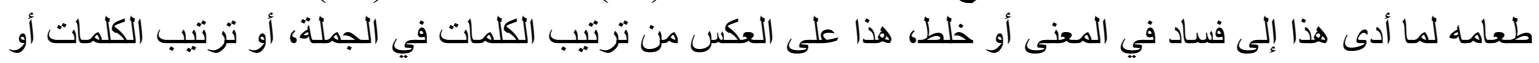

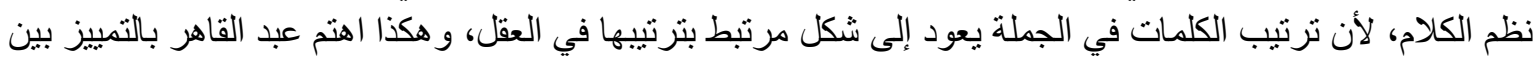

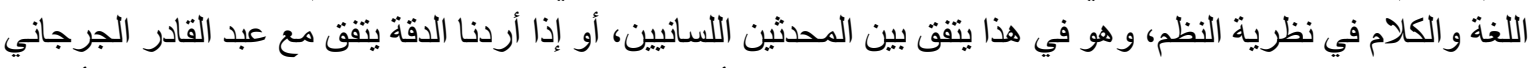

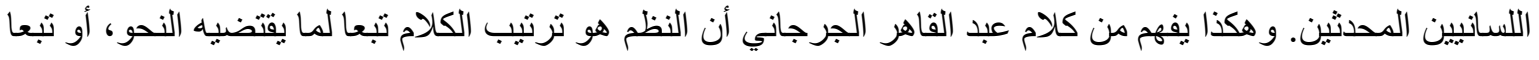

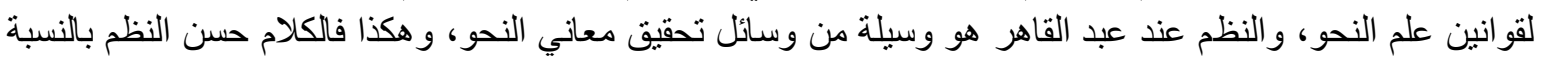

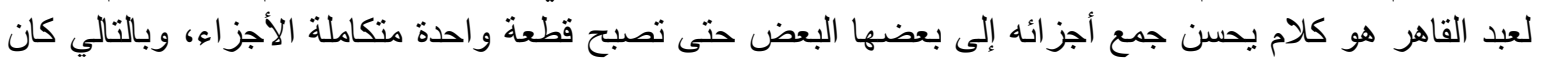

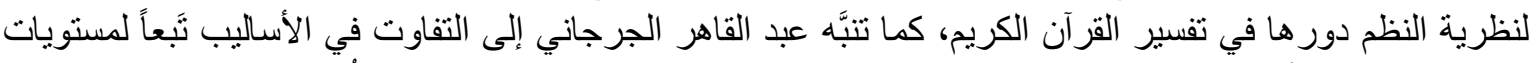

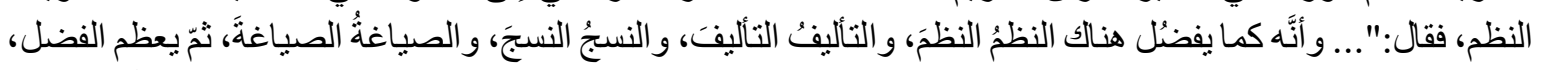
وتكثر المزيَّة، حتى يفوق الثيء نظيره و المجانسَ له درجاتٍ كثيرة... كذلك يفضل بعضُ والنُ الكلام بعضاً... " 58.

وحينما أدرك عبد القاهر الجرجاني تعدُّ أساليب النظم وتفاونها نرك للمبدع الحريّة في اختبار الأسلوب الذي يناسب

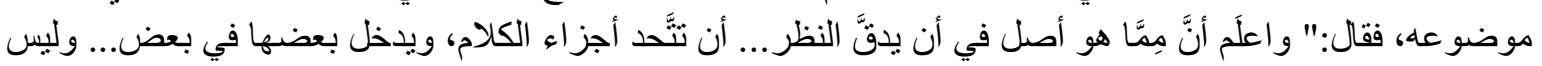

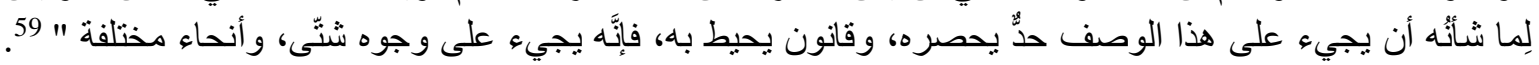

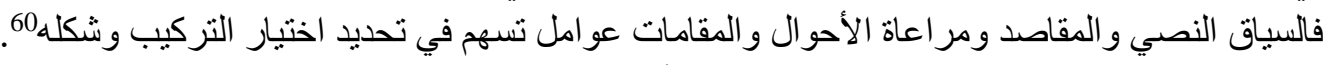

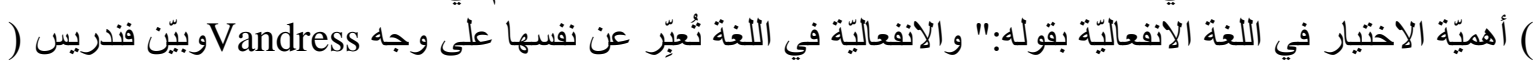

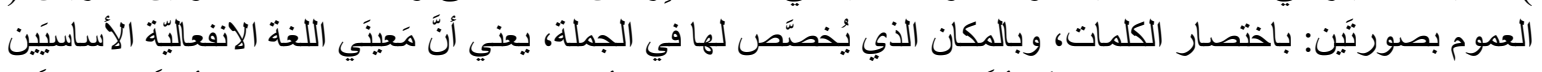

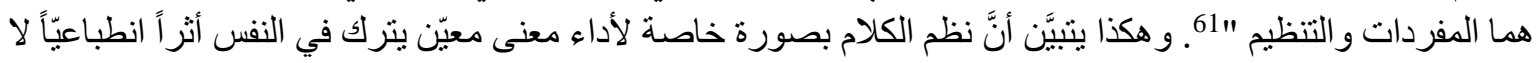

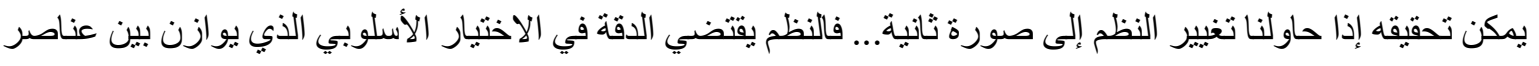
العمل الفني في ضوء المعنى الذي يريد المبدع التعبير عنه.

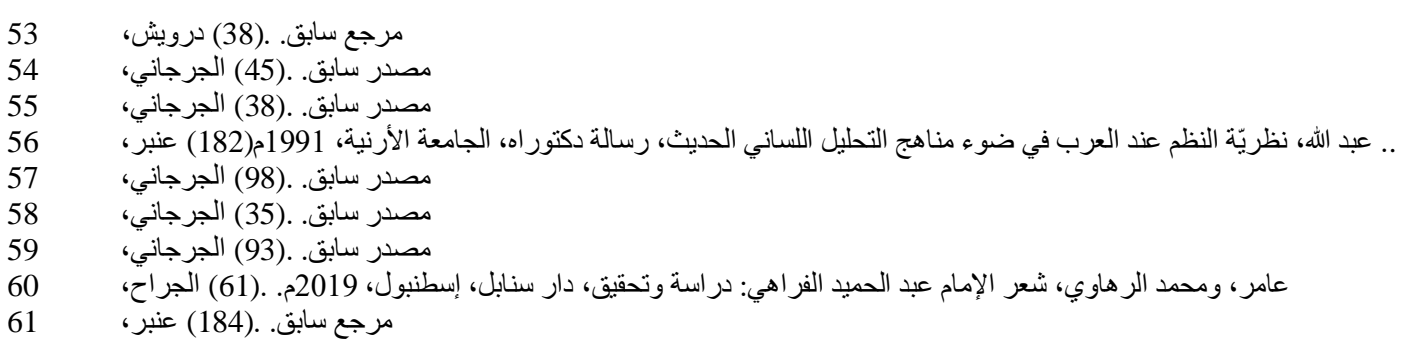




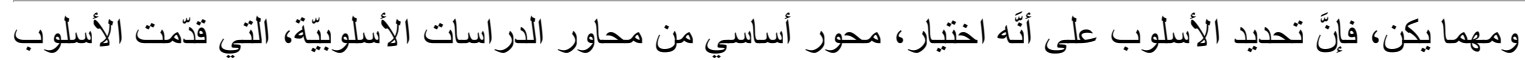

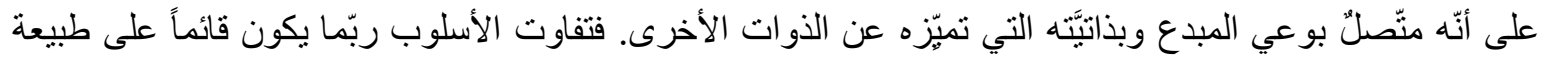

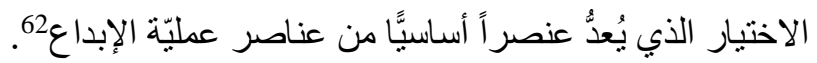

\section{المحور الثَّالث: معنى المعنى في دلائل الإعجاز وعلاقته بالنَّظم}

شكّلت ثنائيّة اللفظ و المعنى جدلاً طويلاً في تاريخ النقد العربي القديم63. وقد تصدَّى عبد القاهر الجرجاني لهذه القضيّة،

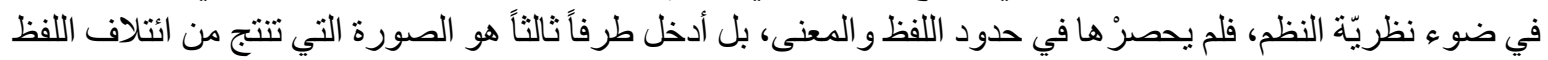

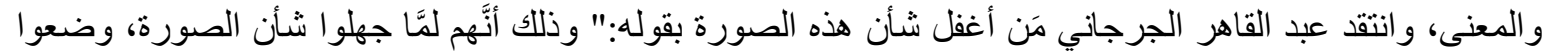

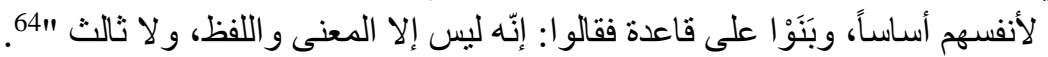

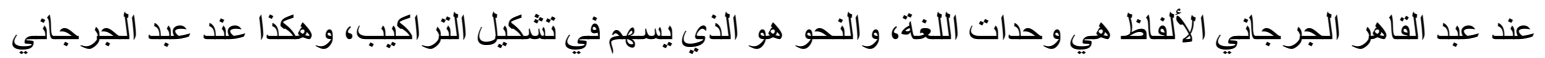

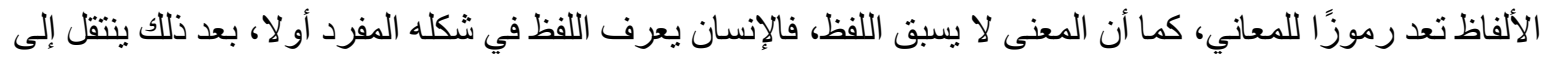

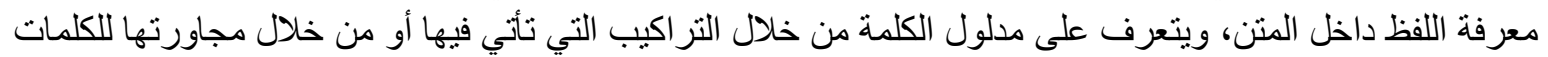
في الجملة، بعد ذللك تأتي المعاني، لتلك اللفظة فقط أو ما يمكن أن نطلق عليه المعنى المعجمي لا يشمل على مزية،

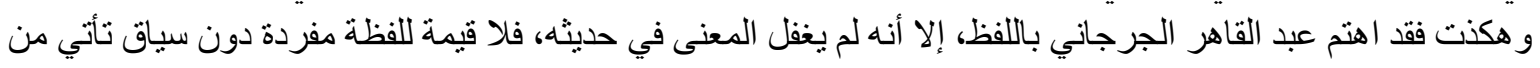

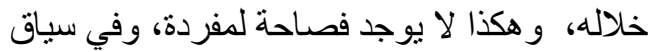

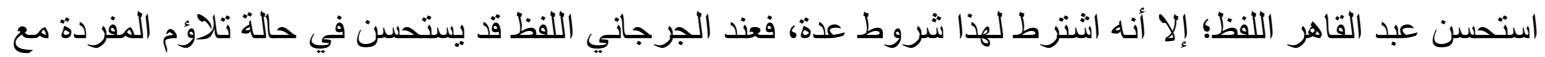

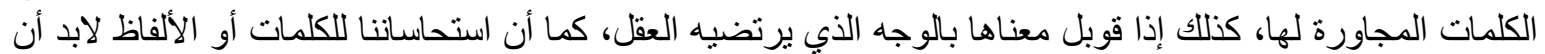

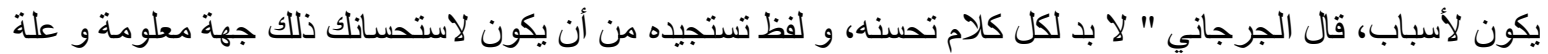

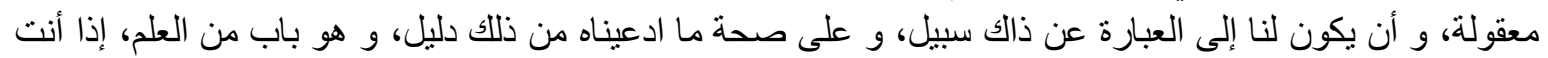

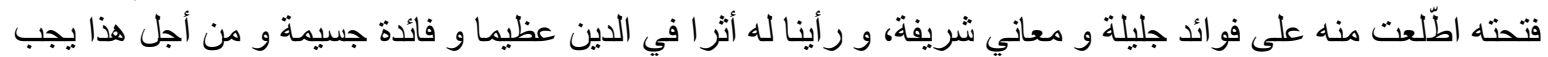

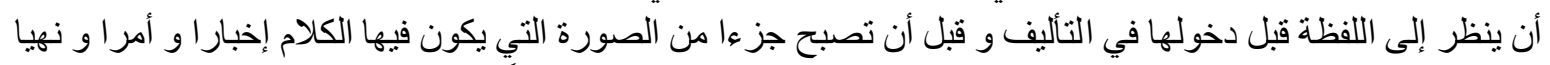

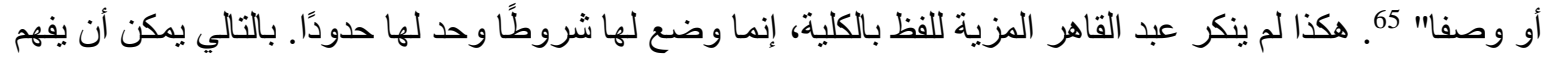

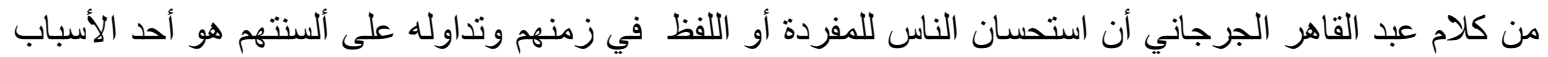

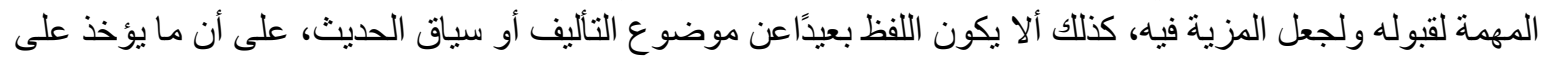

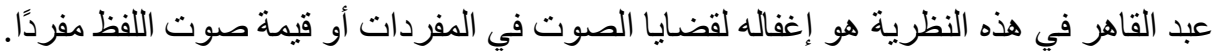
و ون الحديث عن اللفظ و المعنى، انتقل عبد القاهر الجرجاني إلى الحديث عن (المعنى) و و(معنى المعنى)؛ فقال:"الكلام

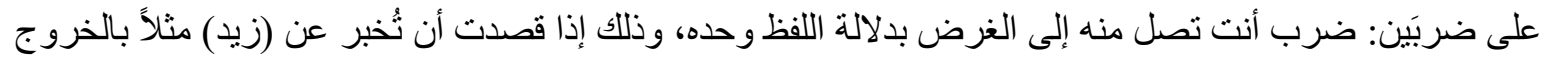

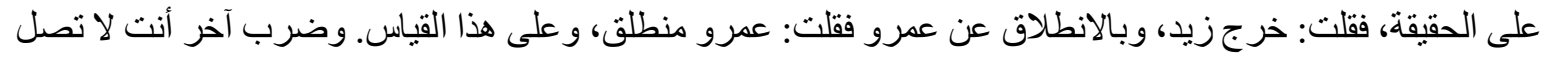

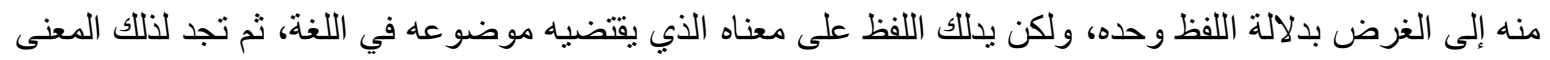

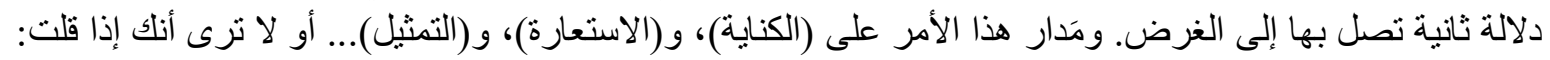

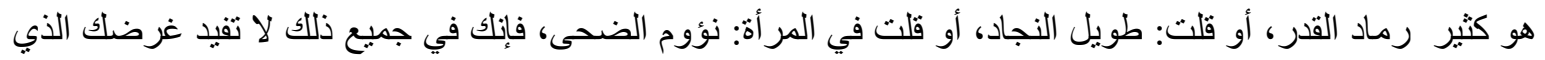

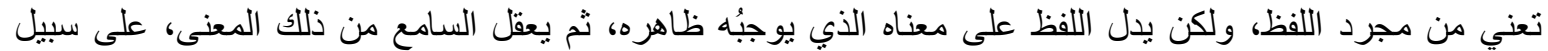

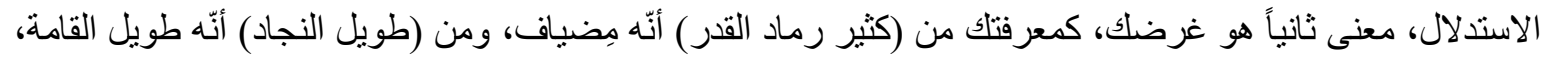

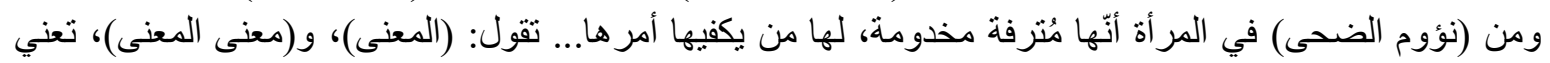

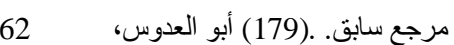

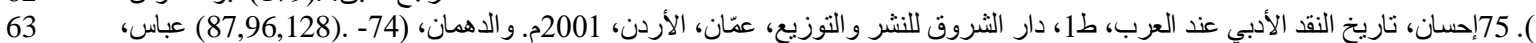

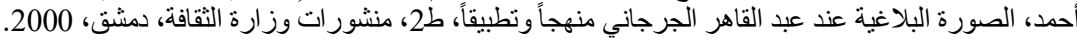

(481). (41). الجرجاني،

مصدر سابق. .(41) الجرجاني، 


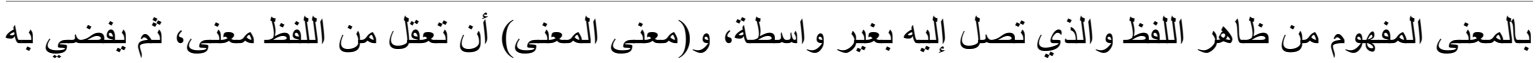

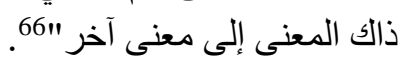

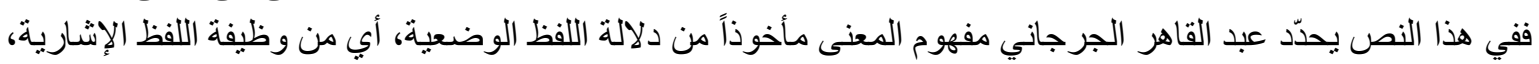

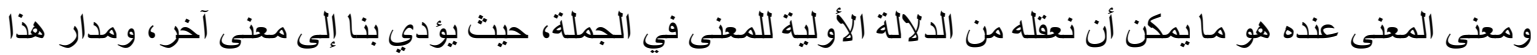

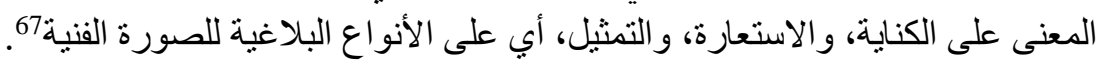

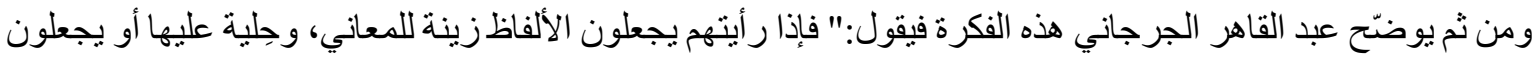

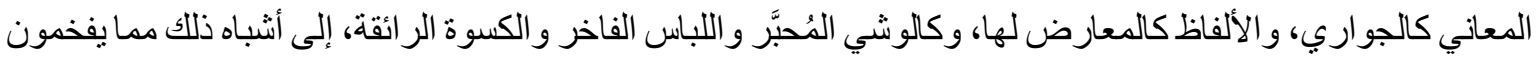

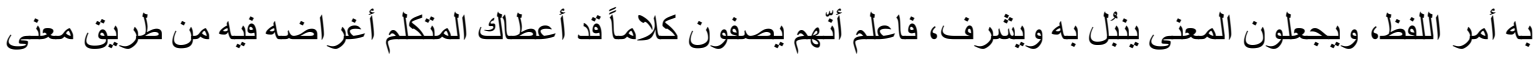

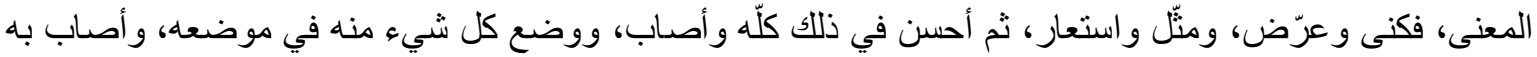

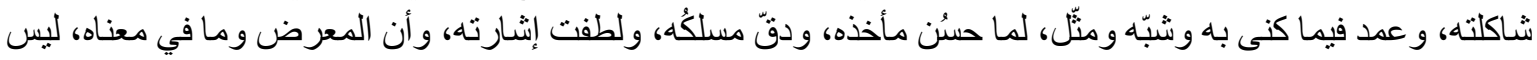

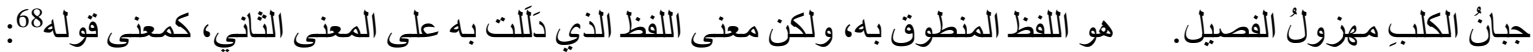

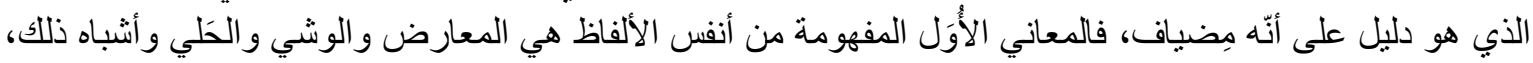

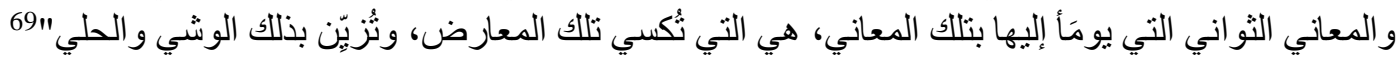

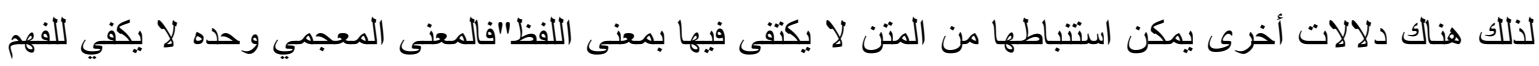

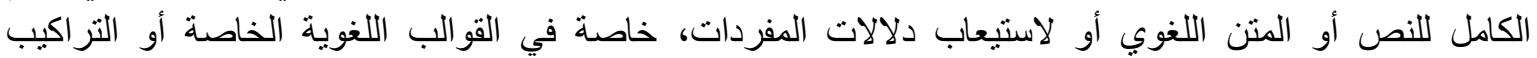

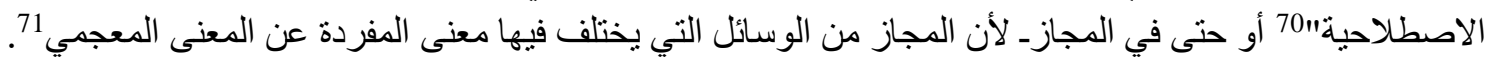

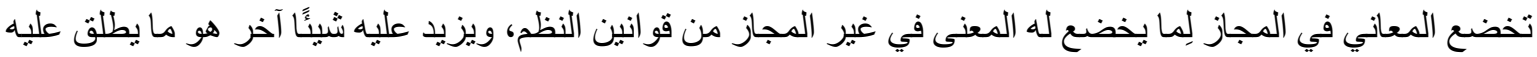

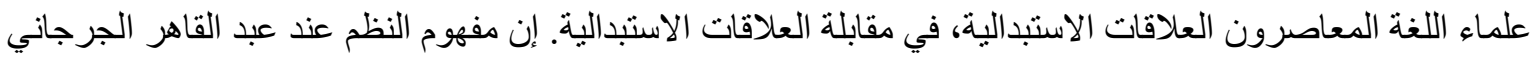

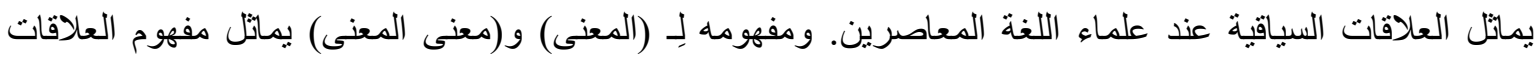

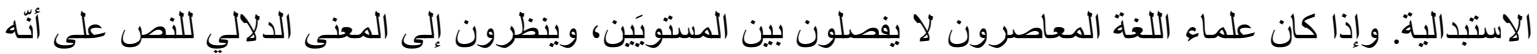

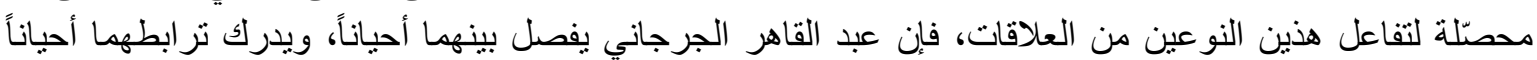

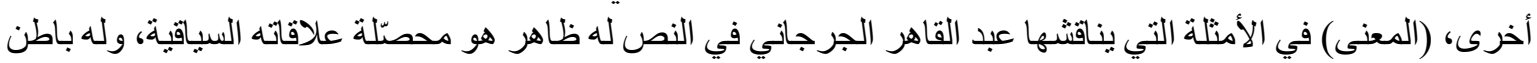

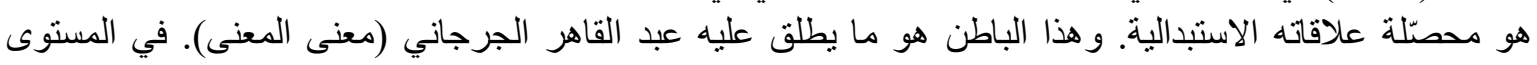

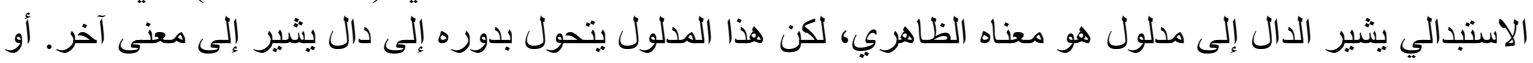

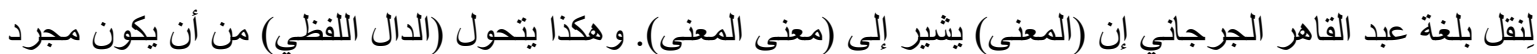

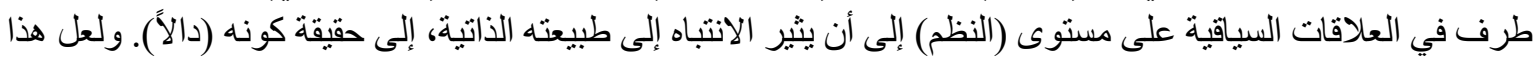

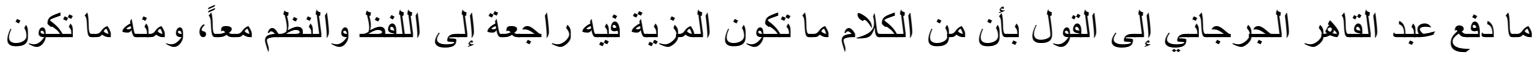

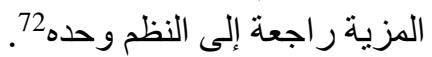

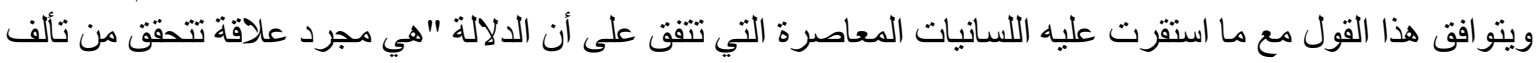

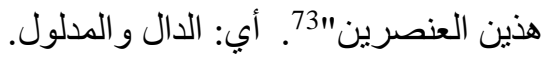

\footnotetext{
66 مصدر سابق. .262-263) (76) الجرجاني، 67

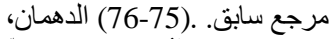

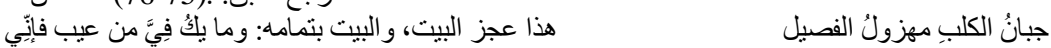

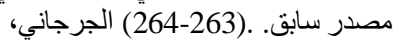

عماد، تغير الدلالات اللغوية لمفردات القرآن الكريم، كتاب جماعي بعنو ان علوم دينية، مشاكل كلاسيكية ومناقثات حالية، مطبو عات . . (134) علي، الجي،

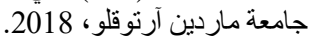

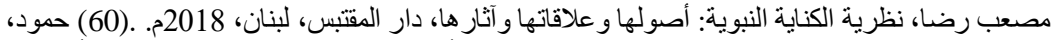

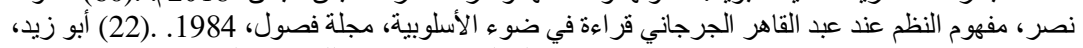

م.1975زكريا، مشكلة البنية، دار مصر للطباعة، القاهرة، . (44) إبراهيم، زئ،
} 


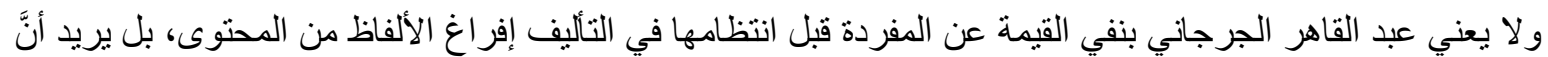

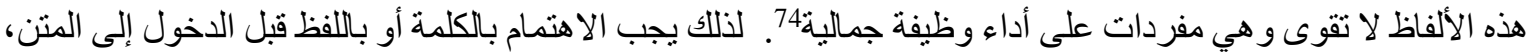

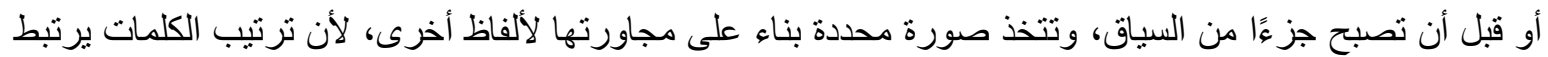

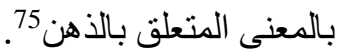

وقد صدر عبد القاهر الجرجاني في مفهومه للمعنى عن نظرته الواعية إلى اللغة بوصفها نظاماً من العلامات، فاللغة كما

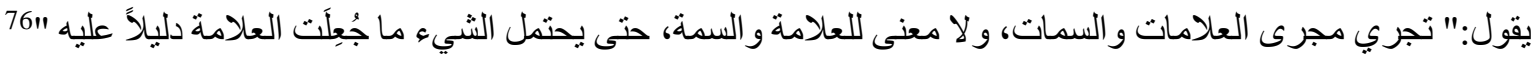

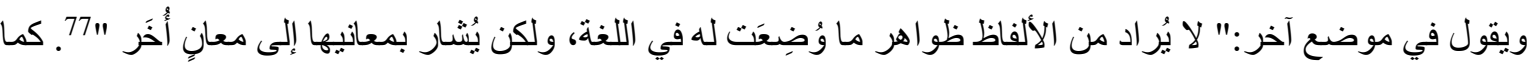

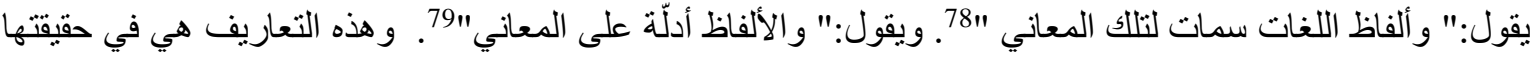

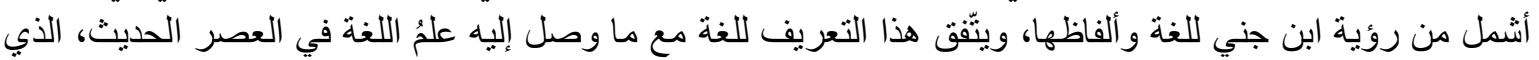

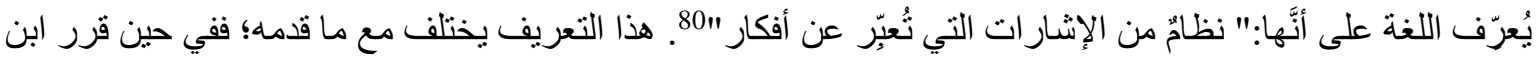

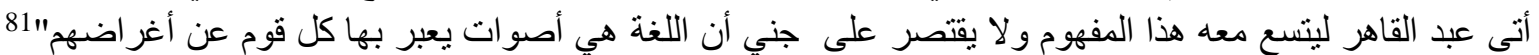

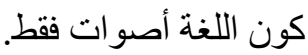

وقد انطلق عبد القاهر الجرجاني في دراسة المعنى وفق هذا المفهوم، إذ إنّه لم ينظر إلى الألفاظ بمعزل عن التز اكيب؛

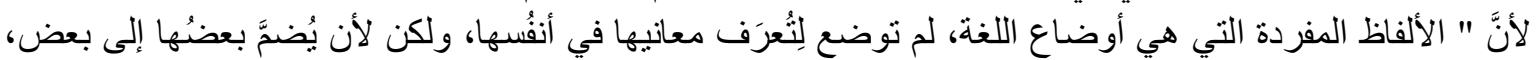

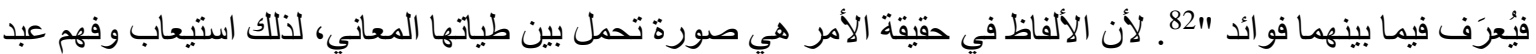

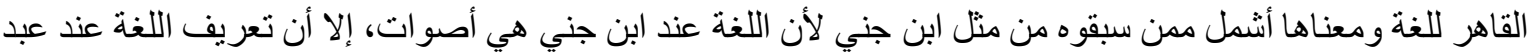

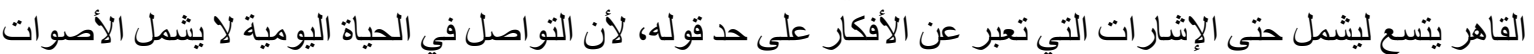

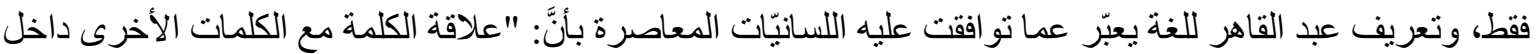
النص هي التي تُحدِّد معناها، و لا معنى لها خارج الخطاب"

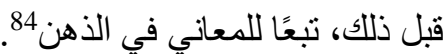

الخاتمة

تييّن من خلال الدر اسة أنَّ الحديث عن نظريّة النظم له إنشار ات عند العلماء العربـ النَّحويين و البلاغيينــ قبل

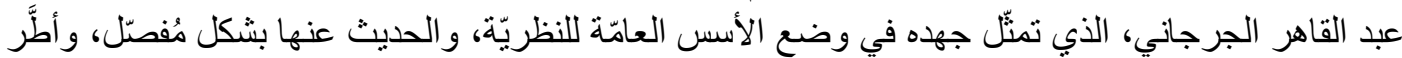

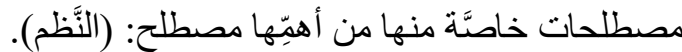

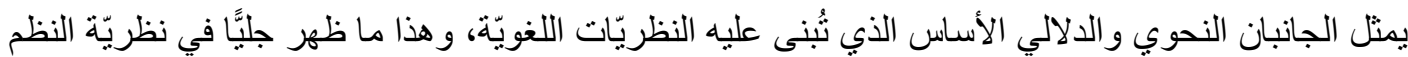

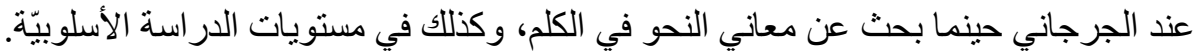

، دار الفكر العربي، بيروت، 1974م. 3عز الدين، الأسس الجمالية في النقد العربي، ط. (132) (403) إسماعيل،

Günaydın,(130-132), Muhammet "The Idea of Multiple Meaningse in al-Jurjani's Theory Of Composition", İstanbul Üniversitesi İlahiyat Fakültesi Dergisi, Say1: 7, 2008.

مصدر سابق. .(44) الجرجاني،

مصدر سابق. . (265) الجرجاني، الجرجي،

مصدر سابق. . (454) الجرجاني، الجرجي،

مصدر سابق. .(483) الجرجاني، (17) الجرجي،

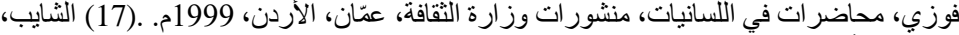

أبو الفتح عثمان ، الخصائص، دار الكتب المصرية، القاهرة، 1952. . (39/2) ابن جني، الأردن،

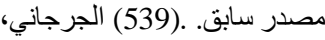

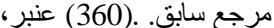

SAĞ ȘENCAL, (35-36), Esma, Mana Oluşumunda İç ve Dış Bağlam İlișkisi : Abdülkahir El-Cürcani ile Saussure Karşılaştırması, Fatih Sultan Mehmet Vakıf Üniversitesi Medeniyetler İttifakı Enstitüsü Medeniyet Araştırmaları Anabilim Dalı, Yayımlanmamış Yüksek Lisans Tezi, İstanbul 2014. 
أوضحت الدّر اسة عن أنَّ النظم عند عبد القاهر الجرجاني، شكّل كثبراً من الركائز التي اعتمد عليها اللغويون المحدثون وكذلك المدارس النقديَّة الحديثة.

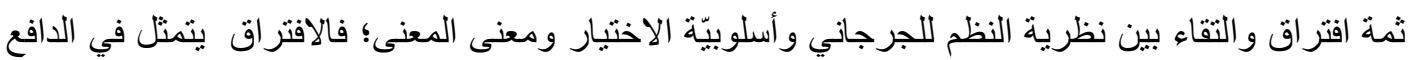

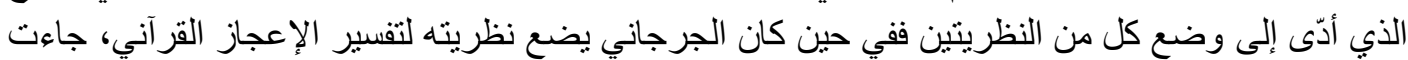

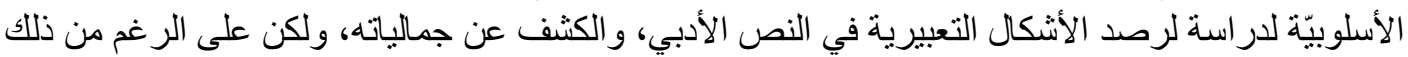

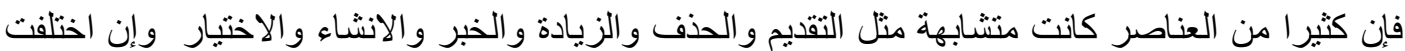

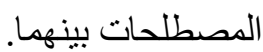

يعتمد مبدأ الاختبار عند عبد القاهر الجرجاني، على اللُّة التي تمنّل خزينة للإِمكانات اللغويّة التي تمكِّن المتكلِّم من تصريف الكلام بحسَب المقام.

"معنى المعنى" عند عبد القاهر الجرجاني، هو الحصبلة الجوهريّة التي توصّل إليها من خلال نظريّته في

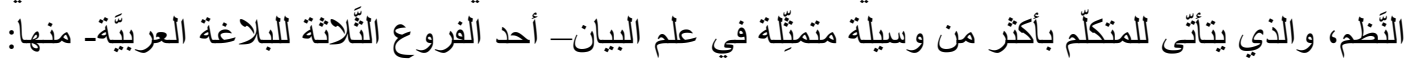

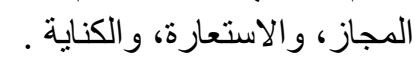

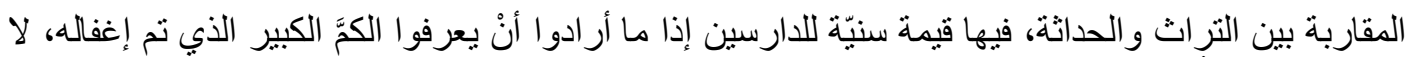
سيّما عند أهل اللُّة العربيّة. أن الأفكار و النظريات في اللغة وإن اختلفت إلا أنها تتلاقى في كثثر من الأحايين؛ فهي عمل بشري تر اكمي يسند بعضه بعضا للوصول إلى الأسس النظريّة و التطبيقيّة التي تحكم اللغة.

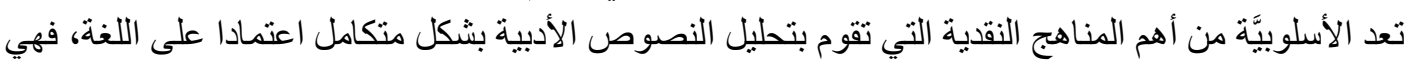

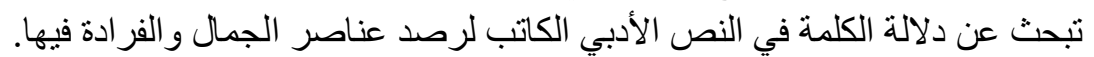

\section{Kaynakça}

Kurân-1 kerîm

$\mathrm{Sa}^{\prime} \mathrm{d}$,

Muhammed,

el-ïhtiyâr

fi'd-dirâsâti 'l-uslûbiyyeti'l-hadîseti, http://www.alfaseeh.com/vb/showthread.php?t=24953 sitesinde geçen makale

Ali, ‘İmâd Abdülbâkî Abdülbâkî, (2019), el-İhâlâtu’l-cuğrâfiyye fî dîvâni Ali el-Cârim, Nüsha Dergisi, Say1: 49, 185-200.

İsmâil, ‘İzzuddîn, (1974). el-Ususu'l-cemâliyye fi'n-nakdi'l- 'Arabiyyi, Dâru'l-fikri'l-'Arabî.

'Ayyâd, Mahmûd, (1981). el-Uslûbiyyetu'l-hadîse muhâveletu ta 'rîf, Mecelletu fusûl.

Mahsûl, Sâmiye, (2011). Uslûbu'l-ihtiyâr fi'd-dirâsâti'l-uslûbiyyeMecelletu dirâsâtin edebiyye, Say1: 10,126-127.

ez-Zehrâ, Şevkî Ali, (1996).el-Uslûb beyne Abdilkâhir ve John Merry: Dirâse mukârene, el-Âdâb.

Maslûh,Sa‘d, (1992). el-Uslûb dirâse lugaviyye ihsâiyye, Âlemu'l-kutub.

Rabâbia, Musâ, (2003). el-Uslûbiyye Mefâhîmuhâ ve Tecelliyyâtuhâ, 1. Bask1., Dâru'l-Kindî li'nneşri ve't-tevzî.

Ebu'l-‘Adûs, Yusuf (2007). el-Uslûbiyyetu'n-nazariyyeti ve't-tatbîk, Dâru'l-mesîra li'n-neşri ve’ttevzî.

el-Museddî,Abdüsselâm (1977). el-Uslûbiyyetu ve'l-uslûb, 1. bask1, ed-Dâru'l-‘Arabiyyeti li'l-kitâb.

Halîl, İbrâhîm (1997).el-Uslûbiyye ve nazariyyetu'n-nass, 1. bask1, el-Müessesetu'l-‘Arabiyyetu li'ddirâsâti ve'n-neşr. 
Ebu Zeyd, Nasr Hâmid, (1996). İşkâliyyâtu'l-kırâati ve âliyyâtu't-te'vîl, el-Merkezu's-sikâfiyyu el'Arabiyyu, ed-Dâru'l-beyzâ.

ed-Dervîş, Muhyiddîn (2001).I' 'râbu'l-kur 'âni'l-kerîmi ve beyânuhu, 8. bask1, Dâru'l-yemâme li’ttıbâati ve'n-neşri ve't-tevzî.

ez-Ziriklî, Hayruddîn (2005).el-A 'lâm, 16. bask1, Dâru'l-'ilm li’l-melâyîn.

el-Endelûsî, Ebû Hayyân (1987). el-Bahru'l-muhît, 2. bask1, Dâru'l-fikr, li't-tıbâati ve'n-neşri ve’ttevzî, Beyrût.

'Allâm, Abdülâti (1993). el-Belâgatu'l-'Arabiyyetu beyne'n-nâkidîne'l-hâlidîn Abdilkâhir elCürcânî ve'bni Sinân el-Hâfâcî, Dâru'l-ceyl.

Abdülmuttalib, Muhammed (1994). el-Belâga ve'l-uslûbiyye, 1. baskı, eş-Şirketu'l-Mısriyyetu'l'Âlemiyye li'n-neşri Longman.

el-Câhiz Ebû 'Usmân 'Amr ibnu'l-bahr, el-Beyân ve't-tebyîn, 1. bask1, Thk. Abdüsselâm Hârûn, Lecnetü't-te'lîf ve'n-neşr.

'Abdülbedî‘, Lütfî (1970).et-Terkîbu'l-luğavîyyu li 'l-edeb, 1. bask1, Mektebetu'n-nahda.

ibnu'l-Cinnî, Ebu'l-Feth 'Usmân (1952).el-Hasâis, Dâru'l-kutubi'l-Misriyye.

'Abbâs, İhsân (2001). Târîhu'n-nakdi'l-edebîyyi, Dâru'ş-şurûk li'n-neşri ve't-tevzî.

Dervîş, Ahmed (1998). Dirâsetü'l-uslûb beyne'l-mu 'âsırati ve't-turâs, Dâru garîb li’n-neşri ve'ttevzî.

El-Cürcânî, Abdülkâhir, (1992). Delâilu'l-i'câz, Tahkîk ve talik: Mahmûd Muhammed Şâkir, 3. bask1, Matbaatu'l-medenî, Kâhire, Dâru'l-medenî.

Dehmân,Ahmed (2000). es-Sûretü'l-Belâgiyye inde Abdülkâhir el-Cürcânî menhecen ve tatbîken, 3. Baskı, Menşûrât Vizâreti's-Sekâfe.

Alî, İmâd Abdülbâki Abdülbâki, (2018). Tağayyürü'd-Delâlâtü'l-lügaviyye li müfredâti'l-Kur'an-ı Kerim, Kitâb Cemâ̂̀ bi unvâni ulûm diniyye. Meşâkilü klâsîkiyye ve münâkaşât hâliyye, Mardin Artuklu Üniversitesi Yayınları.

Amir, er-Rehâvî, Muhammed, (2019).Şi'rü'l-İmâm Abdülhamit el-Ferâhi: Dirâse ve Tahkîk, elCerrâh, Dârü Senâbil.

Fadl, Salâh (1985).İlmü 'l-usûb mebâdiuhû ve icrââtuhû, 2. Bask1, el-Hey'etü'l-Misriyyeti'l-âmme li'l-kitâb.

el-Aşmâvî, Muhammed, (1979).İlmü'l-luğati ve'n-nakdi'l-edebî beyne'l-kadîm ve'l-hadîs, Darü'nNehdati'l-arabiyye.

el-Askerî, Ebû Hilâl el-Hasen b. Abdullah b. Sehl (1984). Kitâbü 's-Sinâateyn, thk. Müfîd Kamîha, 2. Bask1, Dârül-kütübü'l-ilmiyye.

ibn Zerîl, Adnân (2006). el-Luğatu ve'l-uslûb dirâse, Takdim: Hasan Hamîd, 2. baskı, Dâru'1mecdellâvî.

eş-Şâyib, Fevzî (1999). Muhâdarât fi 'l-lisâniyyât, Menşûrâtu vizâreti 's-sikâfeti.

ibn Atiyye, Abdülhakk bin Gâlib (1993).el-Muharraru'l-vecîz fî tefsîri'l-kitâbi'l-'azîz, Thk: Abdüsselâm Abdüşşâfî, 1. baskı, Dâru'l-kutubi'l-'ilmiyye.

Telîme, Abdülmünim (1978).Medâhil ilâ 'ilmi 'l-cemâl el-edebî, Dâru's-sikâfeti li'n-neşr.

İbrâhîm, Zekeriyyâ, (1975). Müşkiletü'l-bunye, Dâru Misr li't-tıbâa. 
Refîde, İbrâhim (1989). Me 'âni'l-kur 'âni'l-kerîm, 1. bask1, Cem'iyyetu'd-da'veti'l-islâmiyyeti'l'âlemiyye, Trablus el-Cemâhiriyyetu'l-'uzmâ.

es-Sekkâkî, Ebû Ya'kûb (1983). Miftâhu'l-'ulûm, Zapt ve talik: Nuaym Zarzûr, 1. bask1, Dâru'lkutubi'l-'ilmiyye.

el-Emîn, Su'âd (2015). Mefhûmu'l-ihtiyâr fi'd-dirâsâti'l-uslûbiyye, Mecelletü'l-âfâk el-edebiyye, Say1: 7, 150-168.

Ebû Zeyd, Nasr Hâmid (1984).Mefhûmu'n-nazm 'inde Abdilkâhir el-Cürcânî Kırâe fì dav'i'luslûbiyye, Mecelletu fusûl.

Hammûd, Mus'ab Rizâ (2018). Nazariyyetu'l-kitâbeti'n-nebeviyye: usûluhâ ve 'alâkâtuhâ ve âsâruhâ, Dâru'l-muktebes.

Anber, Abdullah (1991). Nazariyyetü'n-nazm 'inde'l- 'Arab fì dav'i menâhici't-tahlîli'l-lisâniyyi'lhadîs Doktora Tezi, el-Câmi'atu'l-Ürdüniyye.

el-Bekâî, Burhânuddîn (1995). Nazmu'd-durer fì tenâsubi'l-âyâti ve's-suver, 1. bask1, Dâru'1kutubi'l-'ilmiyye.

Ebû Lihye, Mecdî (2009). en-Nazmu'l-kur 'ânîfî sûreti Hûd: Dirâse uslûbiyye, Yüksek Lisans Tezi, Danışman: Muhammed 'Ulvân, el-Câmi'atu'l-İslâmiyye.

KINAR, Kadir (2006). Abdulkahir El-cürcânî'nin Nazm teorisi, Sakarya Üniversitesi Ilahiyat Fakültesi Dergisi 13, 68-82.

GÜNAYDIN, Muhammet (2008). "The Idea of Multiple Meanings" in al-Jurjani's Theory Of Composition”, İstanbul Üniversitesi İlahiyat Fakültesi Dergisi, Say1: 7. 130-144.

ŞENCAL, Esma SAĞ (2014).Mana Oluşumunda İç ve Dış Bağlam İlişkisi : Abdülkahir El-Cürcani ile Saussure Karşılaşstırması, Fatih Sultan Mehmet Vakıf Üniversitesi Medeniyetler İttifakı Enstitüsü Medeniyet Araştırmaları Anabilim Dalı, Yayımlanmamış Yüksek Lisans Tezi. 